\title{
Political Booms, Financial Crises
}

\author{
Helios Herrera
}

University of Warwick and Centre for Economic Policy Research

\section{Guillermo Ordoñez}

University of Pennsylvania and National Bureau of Economic Research

\section{Christoph Trebesch}

Kiel Institute for the World Economy, Centre for Economic Policy Research, and CESifo

\begin{abstract}
Political booms, measured by the rise in governments' popularity, predict financial crises above and beyond better known early warning indicators, such as credit booms. This predictive power, however, only holds in emerging economies. We argue that governments in developing countries have stronger incentives to "ride" unsound credit booms in order to boost their popularity, rather than implementing corrective policies that could prevent crises but are politically costly. We provide evidence of the relevance of this mechanism, partly by constructing a new cross-country data set on government popularity based on opinion polls.
\end{abstract}

\section{Introduction}

A consistent predictor of financial crises, both in advanced and emerging economies, is the magnitude of the preceding credit boom. Schularick

We thank Harald Uhlig and three anonymous referees for excellent and extensive feedback. We also thank Bennet Berger, Roberto Chang, Jesus Fernandez-Villaverde, Gary Gorton, Stephen Harber, Dirk Krueger, Enrique Mendoza, Moritz Schularick, Aaron Tornell, Francesco Trebbi, Felix Ward, and seminar participants at the Society for Economic Dynamics meetings in Seoul, the Pontifical Catholic University of Rio de Janeiro, Fundação

Electronically published December 19, 2019

[ Journal of Political Economy, 2020, vol. 128, no. 2]

(c) 2019 by The University of Chicago. All rights reserved. 0022-3808/2020/12802-0009\$10.00 
and Taylor (2012), for example, claim that "credit growth is a powerful predictor of financial crises, suggesting that such crises are credit booms gone wrong and that policy makers ignore credit at their peril." ${ }^{1}$ This result poses a challenge to the understanding of financial crises and thus for the design of financial regulation. If a credit boom is a warning signal, why do policy makers not take more corrective steps to control credit expansion? Why are macroprudential policies often too timid, too late, or enacted only after a crisis? Early warning signals, sometimes mixed and unclear, are in many cases paramount and apparent, if not to the general public, then at least to policy makers, who are usually more attentive to the broader economic situation and have access to privileged information. In many circumstances what prevents the implementation of corrective actions seems to be more lack of political will than lack of information. ${ }^{2}$

In this paper, we uncover a robust link between political factors and financial crises, shedding light on the recurring phenomenon of credit booms gone bust. Our main result is that an increase in government popularity (political booms, henceforth) constitutes a powerful predictor of financial crises, above and beyond credit booms. There is an interesting caveat to this result, however: "political booms gone bust" are an emerging market phenomenon only.

To measure government popularity we use the "index of government stability" ( stability index, henceforth), a standardized variable provided by the International Country Risk Guide (ICRG) for over 60 countries since 1984. Additionally, we construct a novel cross-country database on government approval by gathering opinion poll data from national sources in 30 countries, which we find to co-move closely with the ICRG measure. Combining these political time series data with widely used banking crises data, we show that political booms are good predictors of emerging market crises and quantitatively as important as other, better known early

Getulio Vargas of São Paulo, Einaudi Institute for Economics and Finance of Rome, the University of Ottawa, the Wharton School of the University of Pennsylvania, the PRIN (Progetti di Ricerca di Interesse Nazionale) workshop at Bologna, and the Penn Institute for Economic Research-Instituto Tecnológico Autónomo de México Conference on Macroeconomics for comments. Lukas Althoff, Raphael Gressmann, Martin Kornejew, Thomas Ueberfuhr, and Benjamin Wache provided outstanding research assistance. Data are provided as supplementary material online.

${ }^{1}$ Similarly, Mendoza and Terrones (2012) conclude that "not all credit booms end in financial crises, but most emerging market crises were associated with credit booms." Schularick and Taylor (2012) use a database with 14 developed countries since 1870, while Mendoza and Terrones (2012) focus on credit booms for a broader set of countries since 1980. See also Ranciere, Tornell, and Westermann (2008), Claessens, Kose, and Terrones (2011), and Gourinchas and Obstfeld (2012).

2 For evidence on policymakers' availability of information prior to the Asian crisis, see Radelet and Sachs (1998), Corsetti, Pesenti, and Roubini (1999), or the International Monetary Fund (2000). For evidence on the information available to policymakers before the recent European crisis, see Fernandez-Villaverde, Garicano, and Santos (2013). 
warning indicators such as credit booms. In our baseline model, a 1 standard deviation increase in the stability index roughly doubles the probability of a banking crisis in emerging economies, while it has no predictive power in developed ones. This result survives a broad range of robustness checks, such as controlling for asset price booms (stocks, housing), economic growth, fiscal spending, central bank independence, or the electoral cycle. Using our new opinion poll data set on government approval, we also zoom in on the political experiences of 12 major crisis events, providing further support for our results.

Our finding of political booms gone bust makes any potential explanation of financial crises even more challenging: Why are crises more likely to occur after a rise in government popularity, and why only in emerging economies? What makes government popularity a crisis predictor above and beyond macroeconomic and financial variables? To address these questions, we introduce a model in which the quest for popularity gains makes governments less willing to regulate financial markets responsibly, resulting in a higher risk of crises. Our theory focuses only on political factors, without relying on exogenous differences in economic fundamentals, to provide a self-contained mechanism in which governments' political motives determine how policy makers deal (or not) with credit booms and jointly determine the likelihood of financial crises. In a sense, what drives governments' popularity and thus the likelihood of crises is not what governments do (which could be recorded in data and controlled for) but rather what governments avoid doing to stop credit booms.

In the model, there are two types of governments, "good" and "bad." Good governments are more likely to generate good booms, e.g., by introducing policies that create new investment opportunities and justify credit expansion (such as trade and labor reforms, innovation incentives, or more stable institutional environments). These good booms are less likely to end in crisis as they are sustained by healthy economic fundamentals. There may be forces in the economy, however, that sometimes induce the arrival of bad booms, periods of excessive credit expansion fueled only by bubbles, speculation, and unsound fundamentals. ${ }^{3}$ To reduce the probability of an ensuing crisis, governments should regulate the financial sector during bad booms.

If boom types were publicly observable, agents would identify the government type and the right course of action. But when agents cannot easily observe economic fundamentals, they must try to infer the boom and government types from the observed degree of regulation (or lack thereof). And while regulation is the correct policy to respond to bad booms, it is

\footnotetext{
${ }^{3}$ For a model of why credit booms that are not sustained by good fundamentals are more likely to end in crises, see Gorton and Ordoñez (2016). In this paper, we focus instead on governments' incentives to act upon bad booms or not.
} 
also politically costly because it makes agents infer that the government has not been successful in generating a good boom. This results in a "popularity first, versus country first" trade-off for the government: when potential popularity gains are substantial, governments are more likely to avoid corrective actions, thereby increasing the risk of a crisis.

Consistent with our empirical findings, the model generates both a positive correlation between credit booms and political booms and between political booms and subsequent financial crises. These correlations are stronger when there is more scope to improve popularity, which happens when the government quality is relatively uncertain and its popularity is relatively low, two features that are most prominent in emerging markets, as we show. In short, our model provides one potential explanation for the empirical facts that we observe: governments in emerging markets have larger political incentives to abstain from regulation and "ride" unsound credit booms, resulting in political booms gone bust.

A good example of our mechanism is the Mexican financial crisis of 1994-1995. According to Kessler (1998), Haber (2005), and Calomiris and Haber (2014), this crisis had its roots in the highly competitive presidential elections of 1988 in which the long-ruling PRI party won by only a slim margin. Facing strong political opposition and tight fiscal constraints, the newly elected President Salinas opted to privatize the country's banking sector, spending the proceeds on social programs. ${ }^{4}$ The sudden liberalization was not implemented with sufficient regulation and a lending boom ensued, with domestic private credit increasing from less than $10 \%$ of GDP in 1988 to nearly $35 \%$ of GDP in 1994. During the boom the PRI experienced a strong political comeback, with President Salinas's approval rating increasing from about 50\% in 1989 to $80 \%$ in 1993 (Buendia 1996) and a subsequent political victory of the PRI and its candidate Zedillo in the presidential elections of 1994. Just a few weeks later, however, Mexico entered the largest financial crisis in its history. ${ }^{5}$ This was a classic political boom gone bust: a government allowed an unsustainable credit boom to develop while reaping the political dividend of this boom, at the cost of financial fragility. We discuss several other such cases in the paper, including the credit and political booms preceding the Asian crisis of 1997-1998 and the Russian crisis of 1998.

To the best of our knowledge, this is the first paper that demonstrates that there is an important political angle to financial crisis dynamics in emerging economies, both from an empirical and a theoretical standpoint (see, e.g., Bianchi and Mendoza [2012] and Gorton and Ordoñez

${ }^{4}$ As Kessler $(1998,46)$ puts it, "Unable to pursue traditional populist solutions, which typically called for fiscal stimulus, the government turned to the financial sector."

Calvo and Mendoza (1996) describe how the exchange rate collapsed, nonperforming loans skyrocketed, capital inflows came to a sudden stop, and the banking system had to be bailed out and nationalized again, at a cost 4 times the income from the bank sales of 1991 . 
[2014] for related work on the theoretical link between credit and crises). By establishing that political booms are predictors of financial crises we complement other explanations such as domestic credit booms (e.g., Mendoza and Terrones 2012; Schularick and Taylor 2012), external credit booms, such as bonanzas of international capital flows (e.g., Calvo, Izquierdo, and Mejía 2008; Forbes and Warnock 2012; Reinhart, Reinhart, and Trebesch 2017), and productivity growth (Gorton and Ordonez 2016).

The literature that explores the role of political factors around crises is scarce. Chang (2007), for example, shows how political crises and financial crises tend to happen jointly. While also true in our model, our focus is on the predictive power of political booms preceding crises rather than on the political crashes that follow. Our results, obtained from a large panel of countries and crises, are also in line with recent case study evidence: Calomiris and Haber (2014) highlight the political origins of banking crises, presenting historical evidence of countries facing political frictions that resulted in looser banking regulation and more frequent systemic banking crises; Fernandez-Villaverde, Garicano, and Santos (2013) study "political credit cycles" in the run-up to the eurozone crisis; and McCarthy, Poole, and Rosenthal (2013) show how political dynamics in the United States contributed to the buildup of the housing and credit bubble that led to the 2008 financial crisis.

Our focus is on financial crises, but our model can accommodate the role of political factors in other areas, such as fiscal policy, monetary policy, and liberalization regimes, more in line with the political business cycle (PBC) analysis of Drazen (2000), Chang (2001), Brender and Drazen (2008), Azzimonti (2011) and Ales, Maziero, and Yared (2014). ${ }^{6}$ Since potential popularity gains may distort behavior and increase the risk of crises, our paper relates to the literature on political competence, such as Rogoff and Sibert (1988), Rogoff (1990), Persson and Tabellini (2000), and Maskin and Tirole (2004), ${ }^{7}$ in which "good politicians" have incentives to distort an optimal policy to signal their quality. In our paper the welfare-reducing distortion comes, perhaps more realistically, from "bad politicians" and is more likely in developing economies.

The rest of the paper is structured as follows. We start by showing evidence that political booms predict financial crises in emerging economies, above and beyond credit booms and other economic and political

\footnotetext{
${ }^{6}$ Schuknecht (1996) finds a significant effect of elections on fiscal discipline, also arguing that there should be more room for manipulation in developing countries, as checks and balances are weaker and then incumbents have more power over monetary and fiscal policy. Shi and Svensson (2006) also find that a fiscal PBC is especially strong in developing countries, while Tornell and Lane (1999) study distortionary fiscal policy in countries with weak institutions.

7 The PBC literature goes back to Nordhaus (1975) and Lindbeck (1976), but the first paper to incorporate rational voters and office-motivated politicians trying to signal their competence is Rogoff and Sibert (1988).
} 
variables. Then we develop a reputation model that proposes a potential rationalization of these findings based on political motives and suggests why we observe this phenomenon only in emerging economies. Finally, we conclude.

\section{Political Booms Predict Financial Crises}

This section shows that political booms are significant predictors of financial crises above and beyond credit booms, but only in emerging economies. First, we present a new set of stylized facts on political variables and crises: the government stability index increases in the run-up to crises in emerging economies but not in advanced economies. Second, we replicate this pattern more systematically with regressions that control for credit booms and show a range of robustness tests. Our sample consists of 22 advanced economies (AEs) and 40 emerging economies (EMEs), excluding the least developed countries (see the appendix, which is available as an online supplement) and covering the largest time frame allowed by available information on political variables and financial crises (1984-2010 for banking crises). Third, we construct a new data set on government approval from opinion polls in 30 countries to (i) show that the stability index is a good proxy of government popularity and (ii) explore the evolution of government approval around 12 major crises.

\section{A. Political Booms}

To assess the political conditions of a country surrounding financial crises we use data from the ICRG by the Political Risk Service Group, a leading supplier of financial, economic and political risk analysis. This data set was explicitly constructed to provide measures of political risk that are comparable over time across different political settings, including advanced and developing countries, democracies, and autocracies. The resulting political risk measures include 12 components that range from religious and ethnic tensions to corruption, law and order, the role of the military in politics, or external conflicts. ${ }^{8}$

In what follows we focus on the ICRG government stability index (simply stability index, henceforth), which according to the ICRG is an "assessment of both the government's ability to carry out its declared program(s) and its ability to stay in office" (see PRS Group 2004). This indicator ranges from a minimum of 0 to a maximum of 12 and is itself composed of three

${ }^{8}$ The ICRG methodology was developed in the 1980s in conjunction with the US Department of State, and the CIA and builds on research by a large team of country risk experts. ICRG data are well known and widely used by private corporations and academics (examples of economic research that exploits this data include Acemoglu, Johnson, and Robinson [2001], Gelos and Wei [2005], and Alfaro, Kalemli-Ozcan, and Volosovych [2008]). 
subcomponents, namely (i) government unity ("the extent to which the executive/cabinet is coalesced around the government's general policy goals"), (ii) legislative strength ("whether the government can realize its policy program through the legislative arm of government"), and (iii) popular support ("the level of support for the government and/or its leader, based on credible opinion polls"). A key advantage of using this stability index is its wide and standardized coverage, which goes back to 1984 and includes almost all emerging markets.

We consider the stability index as an empirical proxy of a government's popularity, namely, its political strength and support. In what follows we refer to an increase of the stability index as a political boom. In section II.E, we show that the evolution of the stability index captures very well the evolution of government popularity in the countries and time frame in which public opinion polls are available..$^{9}$

\section{B. Financial Crises}

Our main source of financial crises is the widely used data set by Laeven and Valencia (2010, 2012), which covers systemic banking crises worldwide and back to the 1980s. Systemic banking crises are defined as events of major financial distress (significant bank runs, financial losses, and/or bank liquidations) or major policy interventions (financial bailouts) by the government. In total, our sample includes 57 banking crises, of which 37 occurred in EMEs.

We start, however, by motivating our stylized facts with a subset of particularly severe financial crises. Specifically, we select those crises with the largest output losses according to Laeven and Valencia (2012) and combine this ranking with the selection of major crises by Reinhart and Rogoff (2009) and Reinhart and Reinhart (2010). This sample is composed of 20 "major crises" that are uncontroversial in the magnitude of distress they caused to the economy, with an average output loss of $67 \%$ of GDP in EMEs and $43 \%$ of GDP in AEs. ${ }^{10}$ Lastly, for robustness purposes, we use event data on systemic sudden stops during the period 1990-2004,

\footnotetext{
9 The correlation between changes in the ICRG stability index and changes in Institutional Investor's Country Credit Ratings (used, e.g., in Reinhart, Rogoff, and Savastano [2003]) is just .06. This is further evidence that the ICRG index captures experts' beliefs about the political environment above and beyond experts' beliefs about the economic environment.

${ }^{10}$ Specifically, the sample of 20 major crises includes the Asian crisis of 1997 (Indonesia, Malaysia, the Philippines, South Korea, Thailand, and Hong Kong) and other well-known emerging market crises (Russia 1998, Argentina 2000-2001, and Turkey 2000-2001). For advanced economies, the sample includes four of the "big five" (Norway 1987, Finland 1991, Sweden 1991, Japan 1992, but not Spain 1977 as we do not have political risk data before the 1980s), as well as the most recent financial crisis in the United States and Europe (Iceland 2007, Ireland 2007, the United Kingdom 2007, the United States 2007, Greece 2008, Portugal 2008, and Spain 2008).
} 
as compiled by Calvo, Izquierdo, and Mejía (2008). We provide a list of crisis events according to all these definitions in the appendix.

\section{Motivating Facts on Government Stability Prior to Financial Crises}

Figure 1 shows the cumulative percentage change of the government stability index during the 5 years preceding the start of major financial crises (focusing on the 20 most severe events discussed above). We find stark differences between the experiences of advanced and emerging economies. The index increased substantially (on average by $53.7 \%$ ) during those 5 years in emerging economies, including the Asian crisis and the crashes in Russia and Argentina, while the opposite happens (an average decline of $21.5 \%$ ) in advanced economies, not only for crises of the late 1980s and early 1990s, but also for the recent crises affecting the United Kingdom, the United States, and peripheral Europe.

The evolution of the government stability index before major crises and the clear difference between emerging and advanced economies are also documented in figure 2, where the vertical gray bar (at $t=0$ ) shows the crisis onset. The first panel shows how the stability index increases, on average, roughly from about 6 to nearly 10 in the 5 year interval before severe crises in emerging economies. This increase is statistically significant and corresponds to nearly 2 standard deviations of the index. The $90 \%$ confidence bands (dotted gray lines in the figure) are

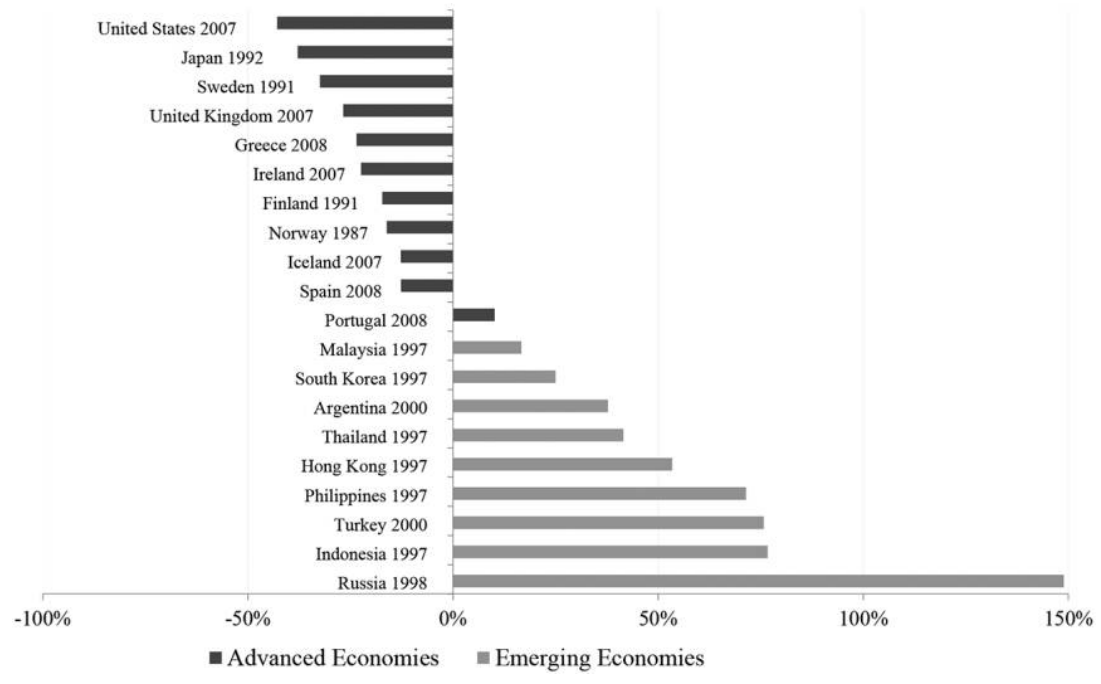

FIG. 1.-Cumulative change in the ICRG government stability index in the 5 years prior to 20 major financial crises. 


\section{Emerging Economies}

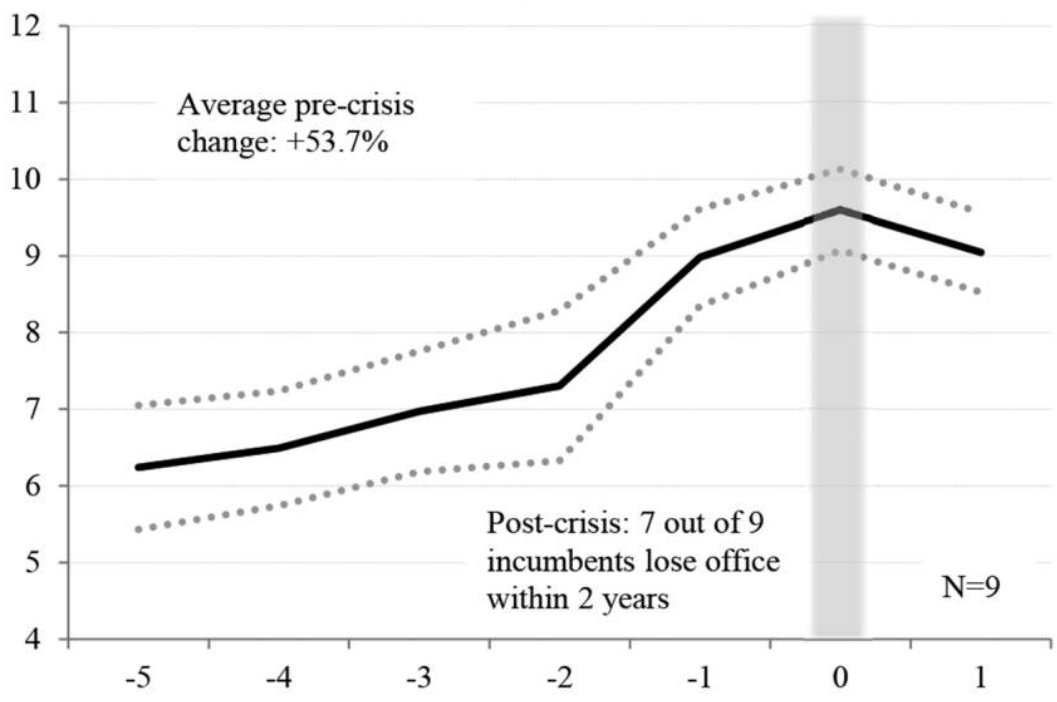

Advanced Economies

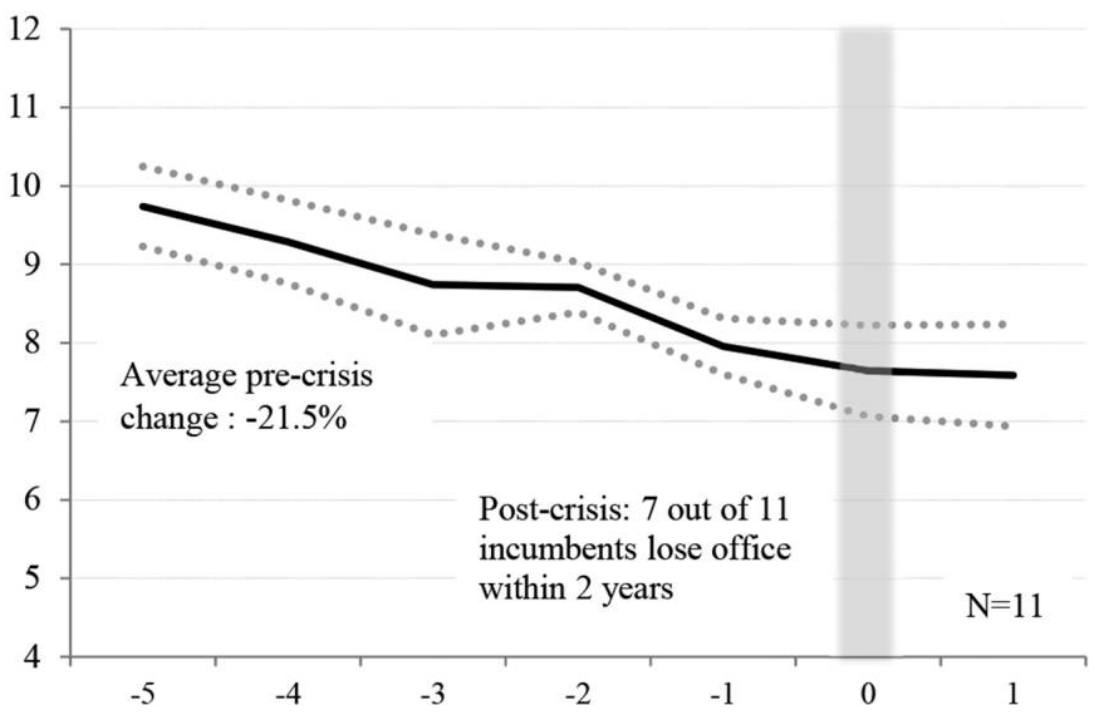

FIG. 2.-Government stability surrounding major crises.

rather narrow, indicating that this dynamic is similar across all crisis episodes in emerging economies. The second panel shows the opposite trend for advanced economies, with the average stability index dropping by about 2 points in the 5 year interval prior to severe crises. The change 
corresponds roughly to 1 standard deviation and is also statistically significant, albeit at a lower confidence level. ${ }^{11}$

The broader sample of banking crises and sudden stop episodes (see figs. B.1 and B.2 in the appendix) reinforces these motivating stylized facts: the stability index increases significantly prior to banking crises and sudden stops in emerging markets and slightly decreases, but not significantly, in the run-up to crises in advanced economies.

\section{Political Booms Predict Financial Crises}

We next assess the relation between popularity and financial crises more systematically, by studying whether political booms predict financial crises when controlling for the size of the preceding credit boom and other economic and political variables that have been shown to increase crisis risks.

\section{Empirical Strategy and Main Finding}

We follow the literature on early warning systems, in particular the empirical strategy of Schularick and Taylor (2012), who examine the role of credit booms in predicting banking crises in 14 advanced economies back to the late nineteenth century. We estimate panel ordinary least squares (OLS) and probit regressions using a binary variable for the starting year of banking crises as the dependent variable. The key distinctive feature of our approach is the addition of political booms to credit booms. Because of data availability we focus on a shorter time span but broaden the country sample from 14 to 62 countries, thereby including emerging economies. The following two regression specifications constitute our benchmark: panel OLS (linear probability),

$$
\operatorname{crisis}_{i t}=\beta_{1}(L) \Delta \operatorname{Credit}_{i t}+\beta_{2}(L) \Delta \operatorname{GovStab}_{i t}+\beta_{3}(L) X_{i t}+\theta_{i}+e_{i t},
$$

and probit,

$\operatorname{probit}\left(\operatorname{crisis}_{i t}\right)=\beta_{1}(L) \Delta \operatorname{Credit}_{i t}+\beta_{2}(L) \Delta \operatorname{GovStab}_{i t}+\beta_{3}(L) X_{i t}+\theta_{i}+e_{i t}$,

where crisis $_{i t}$ is a binary variable for the start of a crisis in country $i$ in year $t, \Delta$ Credit $_{i t}$ is the (year on year) percentage point change in the credit

${ }^{11}$ We do not show the evolution of the stability index after crises in these figures, since our main focus is on the precrisis period. Moreover, the before-after comparison is contaminated by the fact that governments entering a crisis often lose office shortly after, so that we would compare the stability of two different governments, one that entered the crisis and one that assumes power right afterward. In our sample of severe crises, 7 of 9 emerging countries experienced a change in the executive (i.e., in the ruling party or president) within 2 years after the crisis. In advanced economies, the turnover count was 7 of 11 . We further explore the evolution of popularity before and after crises in sec. II.E.2 using poll data on government approval that allow identification of the different governments. Funke, Schularick, and Trebesch (2016) provide a long-run analysis on the political aftermath of crises. 
over GDP ratio, ${ }^{12} \Delta$ GovStab $_{i t}$ is the (year on year) change of the stability index, $L$ is a lag operator which is greater than or equal to $1, X_{i t}$ is a vector of control variables, $\theta_{i}$ are country fixed effects, and $e_{i t}$ is an error term.

Table 1 shows the results using banking crises. Consistent with Schularick and Taylor (2012) the preceding increase in credit (a credit boom) is a statistically significant predictor of a banking crisis in our broader sample. With regard to political booms, we find no clear-cut effect in the full sample (col. 1), as lagged changes in the stability index are not significant. The picture changes drastically, however, once we account for the type of country: in the subsample of emerging economies, the sum of the lagged coefficients is positive and significant at the $5 \%$ confidence level, while this is not the case for advanced economies (cols. 2 and 3). Columns 4 and 5 show our preferred baseline specifications for the full sample with an interaction term for emerging economies. Columns 6 and 7 confirm the results on political booms using yearly lags in credit growth or a 3 year moving average of changes in the stability index, respectively.

Quantitatively, the coefficients are large. In the OLS regressions, the sum of the interaction term coefficients of $\mathrm{EME}_{i} \times(L) \Delta \mathrm{GovStab}_{i t}$ has a value of about .04 (cols. 4 and 6). A 1 point increase in the stability index (year on year) increases the probability of a crisis by nearly 4 percentage points. This is substantial, given that the probability of a crisis in this sample is $3.9 \%$ overall and that the change of the stability index has a standard deviation of 1.14. Put differently, a political boom, defined as a 1 standard deviation increase in government stability during 3 years, more than doubles the predicted probability of a banking crisis in emerging markets (from $3.9 \%$ to $8.2 \%$ ), after controlling for credit booms.

Importantly, political booms and credit booms seem to reinforce each other as crisis predictors in EMEs, as shown in column 8 of table 1 with a specification that interacts changes in credit with changes in the stability index. Figure 3 illustrates this interaction based on that specific regression. We plot the estimated coefficient of $\Delta$ Credit $_{i t}$ as a function of $\Delta$ GovStab $_{i t}$ and the $90 \%$ confidence bands (dotted lines). Credit growth is statistically significant (lower confidence band above zero) only when the stability index increases as well. ${ }^{13}$ This suggests that the crisis risks

\footnotetext{
Using alternative measures of credit growth, in particular the percentage change of the credit/GDP ratio (instead of first differences) or the deviation from trend in real credit (in percent), affects the predictability of credit booms but not of political booms.

${ }^{13}$ For illustration, the change in credit has a coefficient of .0025 when there is no change in government stability. Thus, with no change in the stability index (zero on the horizontal axis in fig. 3), an increase in credit growth by 1 standard deviation (4.8 percentage points) is associated with a 1.2 percentage point higher crisis probability (namely, $.0025 \times 4.8=.012$ ). However, when $\Delta$ GovStab $_{i t}$ increases from zero to 1 , on average, the coefficient for credit growth doubles to .005 . A 1 standard deviation increase in credit growth then translates into a 2.4 percentage point higher crisis probability (namely, $.005 \times 4.8=.024$ ).
} 


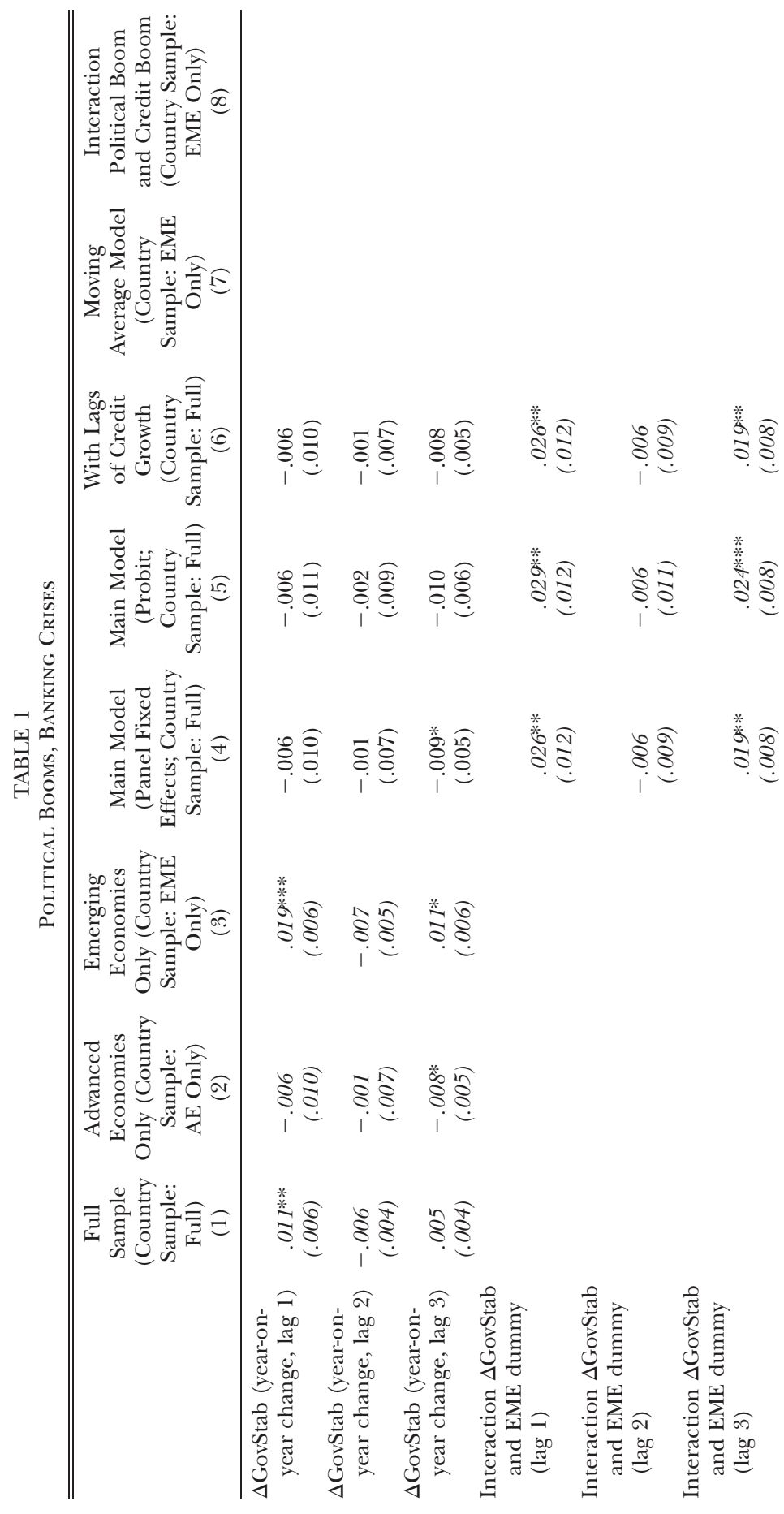

518

This content downloaded from 035.176.047.006 on February 24, 2020 11:39:28 AM 
$\stackrel{\text { ํ. }}{8}$

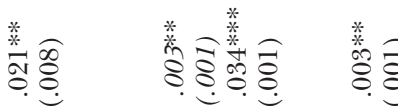

응

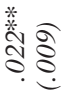<smiles>C1=C[Ge]2C=C[Ge]1C2</smiles>

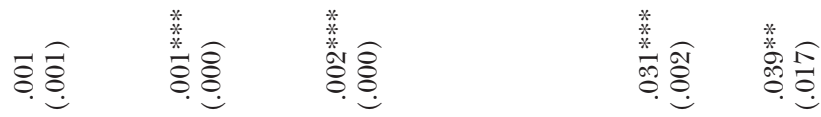

$\stackrel{*}{*} \underset{8}{\stackrel{*}{8}}$

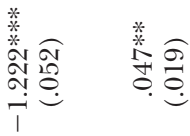

*

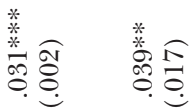

$\stackrel{*}{\stackrel{*}{8}} \stackrel{0}{8}$

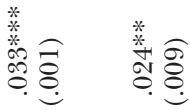

$\stackrel{*}{*} \stackrel{*}{8} \underset{8}{8}$

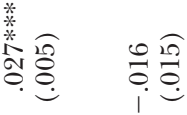

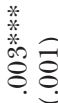

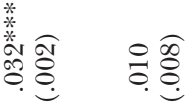
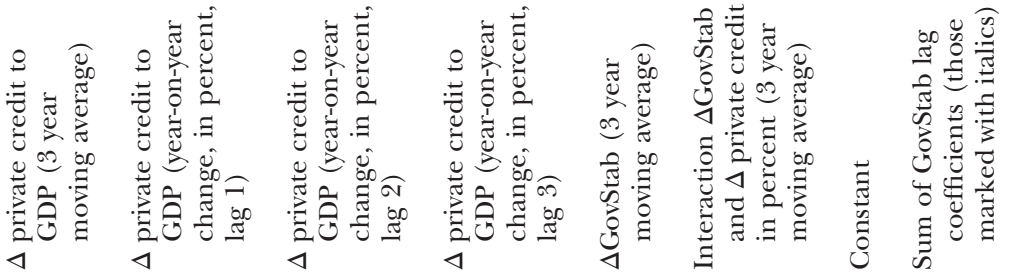

519

This content downloaded from 035.176.047.006 on February 24, 2020 11:39:28 AM All use subject to University of Chicago Press Terms and Conditions (http://www.journals.uchicago.edu/t-and-c). 


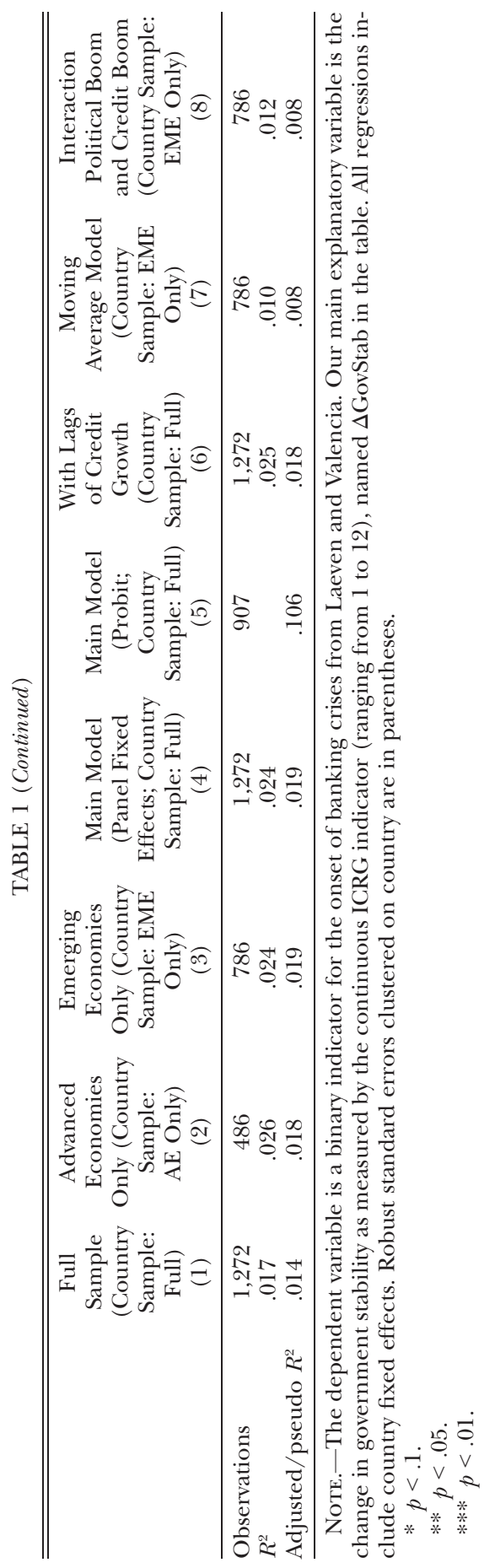

This content downloaded from 035.176.047.006 on February 24, 2020 11:39:28 AM 


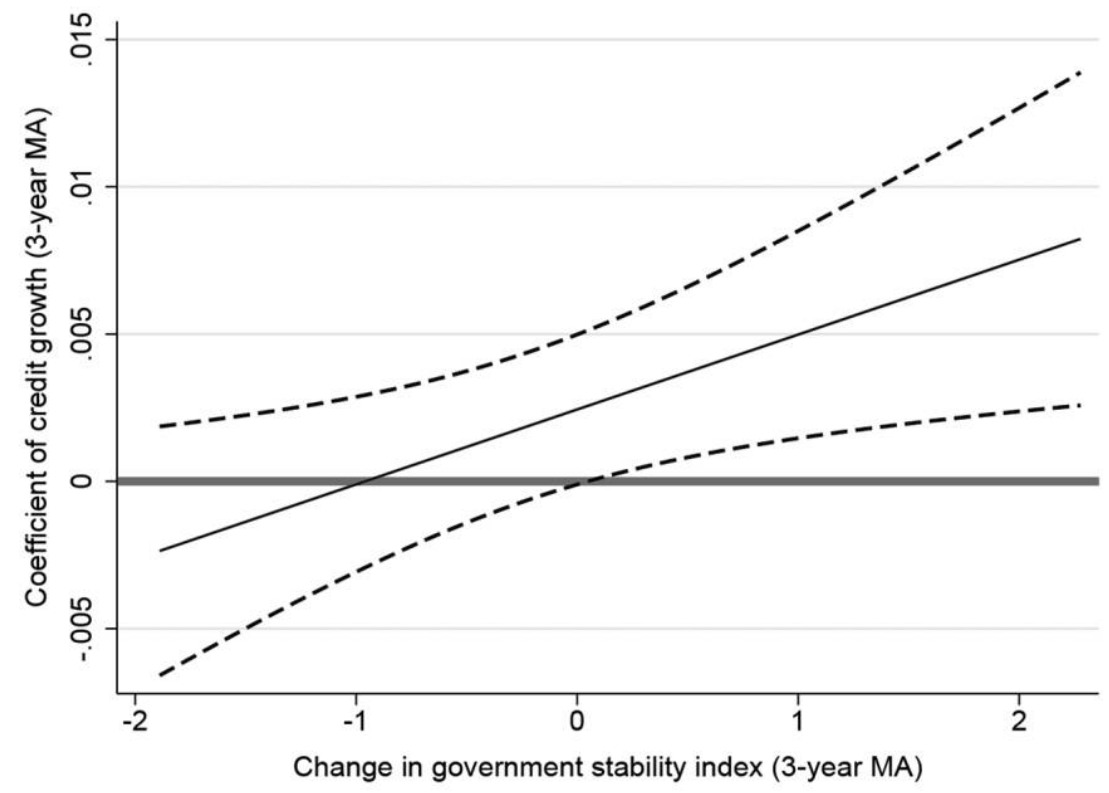

FIG. 3.- Interaction between political booms and credit booms; MA = moving average.

associated with a credit boom in emerging markets are significantly larger in the presence of a contemporaneous political boom.

\section{Goodness of Fit}

In figure 4 we illustrate the power of political booms as a crisis predictor in comparison with credit booms, using a standard diagnostic test for binary event classification, the receiver operating characteristic (ROC) curve. $^{14}$

In particular, the black line shows the ROC curve of our main model (model 1) for both credit booms and political booms based on the regression of column 5 in table 1. Model 2 (light gray line) uses credit booms only, and model 3 (dark gray line) uses political booms only.

Intuitively, the ROC curve illustrates how a signal (e.g., credit/political boom) performs as a crisis predictor. Performance is the ability of the signal to correctly identify positive cases (crisis) and not identify negative cases (no crisis), across all possible signal levels (credit and/or popularity changes). The horizontal axis shows the false positive rate, that is, how often, if no crisis happens in the sample, the signal predicts a crisis, while

14 The ROC curve was first discussed in signal detection theory (Peterson, Birdsall, and Fox 1954) and then introduced into psychology, and it is now applied in several fields, particularly medicine. For a classic text on ROC techniques, see Green and Swets (1966). 


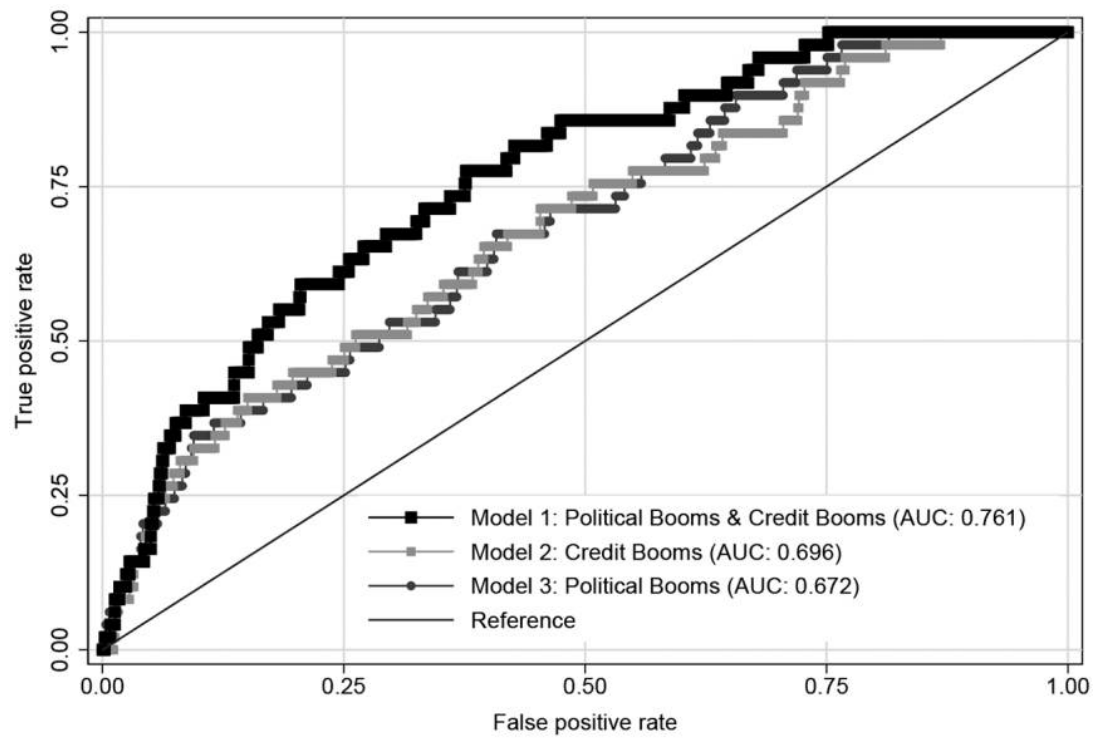

FIG. 4.- Receiver operating characteristic curve (probit with country fixed effects).

the vertical axis shows the true positive rate, that is, how often, if a crisis occurs in the sample, the signal predicts a crisis. For example, the ROC curve of model 2 in the figure shows that a credit boom threshold level that predicts a crisis when there is one, say, around $50 \%$ of the time ( $y$-axis), also predicts a crisis when there is not one about $25 \%$ of the time ( $x$-axis).$^{15}$

Thus, a ROC curve closer to the upper left corner and far from the diagonal indicates a better model fit. This fit is captured numerically by the area under the curve (AUC), which ranges between .5 and 1. An AUC value of .5 means that the model performs no better than tossing a coin ( $45^{\circ}$ line), while a value of 1 indicates perfect prediction, with no false alarms. The estimated AUC can thus be tested against the null hypothesis of a .5 value. While both models 2 and 3 (with only credit booms or political booms, respectively) outperform the coin-toss benchmark significantly (the difference between their AUC test is not statistically significant) and have a similar predictive power, credit booms and political booms are different and independently informative predictors of crises, as the AUC statistic for model 1 is a high .76, which is significantly higher than model 2 or model 3 at a $5 \%$ significance level.

Equivalently, as an alternative to the ROC curve we can use a contingency table to illustrate the predictive power across specifications. Table 2 shows

\footnotetext{
${ }^{15}$ Similarly, choosing a very low credit boom threshold level to achieve a near-perfect true positive rate (e.g., around $95 \%-98 \%$ on the $y$-axis) comes at the cost of a high number of false alarms (around $75 \%$ on the $x$-axis).
} 
TABLE 2

Contingency Table for the Predictive Power of Credit and Political Booms

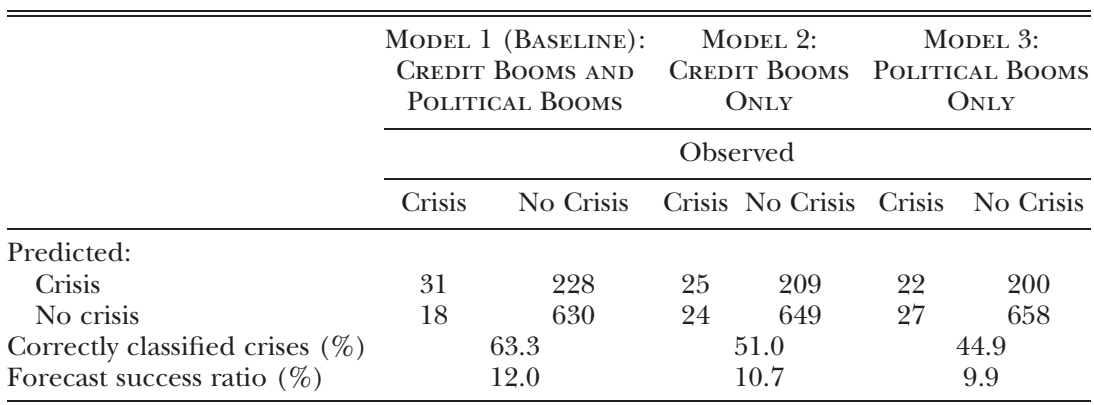

NoтE.-This table shows the number of correctly/wrongly classified crisis/noncrisis years for the full sample (advanced and emerging economies), building on the probit model from col. 5 of table 1. Analogously to fig. 4, we assess the predictive power of different model specifications. Model 2 includes only credit booms, meaning lags of the growth of private credit to GDP; model 3 includes only political booms, meaning lags of the change in government stability. The classification threshold is set to .063 to strike a balance between sensitivity and specificity of the model. Crises are classified as "predicted" if the predicted crisis probability exceeds this threshold. "Correctly classified crises" denotes the share of correctly classified crises in total observed crises. The "forecast success ratio" is the fraction of correct crisis signals in total model signals, computed as (correctly identified crises) / (false alarms + correctly identified crises). The data on banking crises are from Laeven and Valencia. See sec. C of the appendix for more details on contingency tables as well as in-sample and outof-sample prediction results for the EME sample.

how many of the 49 crises in the sample, and of the 858 no-crisis events, were correctly classified by each model. The last two rows show the fraction of observed crises that were correctly predicted by the model [for model 1, e.g., $31 /(31+18)=63.3 \%$ ] and the forecast success ratio (FSR), which is the fraction of predicted crises that were really a crisis [for model $1,31 /(31+228)=12 \%]$. To put these numbers into perspective, the coin-toss benchmark is given by the unconditional probability of a crisis, which in our sample is $5.4 \%$ (namely, 49/49+858).

The results show that models 2 and 3 (which consider only one type of boom) have a forecast accuracy that is twice as high as tossing a coin, while model 1 , which includes both boom variables, more than doubles it. ${ }^{16}$ In particular, both accuracy measures (i.e., the fraction of correctly classified crises and the FSRs) are similar between models 2 and 3, while model 1 outperforms the other models under both measures. These results are quantitatively similar to those of earlier work showing contingency tables for

${ }^{16}$ These results are based on a classification threshold of .063 above which the model sends a crisis signal. We chose this specific threshold on the basis of plotting the FSR for various alternatives, so as to strike a balance between the model's ability to correctly predict crises when they occur and its ability to avoid false alarms. For more discussion about the effects and choice of the classification threshold see the appendix. 
banking crises based on several economic and financial variables. Goldstein, Kaminsky, and Reinhart (2000), for instance, show a battery of economic variables that improve the forecast accuracy of banking crises in a range between $50 \%$ and $100 \%$ above the coin-toss benchmark. In a nutshell, these results confirm that political variables are as relevant as economic variables when forecasting banking crises.

In sum, these tests display two key findings. First, political booms are as good predictors of crises as credit booms. Second, credit booms and political booms are different and independently informative predictors of crises.

\section{Robustness Checks}

We conduct a large battery of robustness checks. Table A.2 of the appendix contains a summary of all variables used and their details and data sources.

First, we modify the estimation approach by running (i) random effect regressions (no country fixed effects), (ii) probit regressions, (iii) regressions that include year fixed effects, which capture potential contagion effects, (iv) regressions that correct for autocorrelation in the standard errors, and (v) regressions that exclude the two main crisis clusters in our sample (the Asian crisis of 1997 and the financial crisis of 2008). These changes have little impact on the results. We also control for countryspecific economic variables that may affect the probability of crises, such as macroeconomic fundamentals and asset prices. In particular, we account for (i) growth of real GDP, (ii) changes in real house prices, (iii) changes in real stock prices, ${ }^{17}$ (iv) the current account balance (as a fraction of GDP), (v) changes in household consumption (as a fraction of GDP), (vi) yearly inflation (in percent), and (vii) the change in a country's terms of trade.

Second, we control for country-specific political and institutional factors, in particular, (i) autocratic or quasi-autocratic regime (defined by a democracy index from the Polity data set), (ii) the political system (presidential vs. parliamentarian), (iii) the quality of institutions (a measure of executive constraints, also from the Polity data set, and indicators of bureaucratic quality and the rule of law), (iv) the independence of the central bank (cross-sectional data from Segalotto, Arnone, and Laurens [2006]), (v) government turnover (a dummy for "new government," which captures whether the government has been in office for 1 or 2 years

${ }_{17}$ The results with stock and house prices are similar if we use deviation from trend instead of growth rates. 
only, from the Database of Political Institutions [DPI]), (vi) the political orientation of the government (a dummy for left-wing governments from the DPI), (vii) wars and conflicts (both with data from the ICRG and the Correlates of War project), (viii) the electoral cycle ("years until next election" and "years in office" from the DPI), and (ix) disruptive political events, in particular, "major government crises" and "major cabinet changes" from Banks and Wilson (2013), federal elections (from the DPI), and public protests (number of "general strikes" and "violent street riots," also from Banks and Wilson). As a catch-all measure we also control for country credit ratings, using the comprehensive data by Institutional Investor magazine, which goes back to the 1980s for most developing countries.

Tables B.1 and B.2 in the appendix show that none of these additional controls affect the results qualitatively or quantitatively. As for potential nonlinear effects, ${ }^{18}$ adding second- and third-order polynomials of our credit or political boom variables leaves the results unchanged.

Table B.3 in the appendix shows some of these results for the subsample of emerging markets. Instead of adding control variables one by one we include them simultaneously. ${ }^{19}$ Again the main coefficients on government stability remain stable and the control variables themselves are mostly insignificant and/or show small coefficients.

Finally, we test the relevance of political factors for another type of financial crisis, systemic sudden stops, by replacing the dependent variable with the sudden stop measure compiled by Calvo, Izquierdo, and Mejía (2008) for 36 countries from 1990 to 2004. Table B.4 in the appendix confirms that changes in the stability index are a significant predictor also of sudden stops, above and beyond credit booms. Quantitatively, both the effects and the predictive power of political booms are again large. ${ }^{20}$

\section{Out-of-Sample Performance}

To further assess the goodness of fit of our models we conduct out-ofsample tests following the recent literature on financial crisis prediction

\footnotetext{
${ }_{18}$ It is possible that an increase in government stability is a by-product of credit booms that become particularly pronounced at certain levels. If this is the case, our finding on political booms might merely capture a nonlinear function of credit growth.

${ }_{19}$ We thank a referee for suggesting that we also present the results for emerging and advanced economies separately.

${ }^{20}$ In the main model (col. 4 of table B.4 in the appendix), the sum of the three interaction term coefficients of $\mathrm{EME}_{i} \times(L) \Delta \mathrm{GovStab}_{i t}$ implies that a 1 point increase in the stability index (less than 1 standard deviation) is associated with a 6.7 percentage point higher probability of facing a sudden stop. The AUC statistic resulting from the probit model is a high .79 and statistically different from a coin-toss model. The results are also robust to the checks performed for banking crises.
} 
(e.g., Schularick and Taylor 2012; Catao and Milesi-Ferretti 2014; Ward 2017). The appendix contains a detailed discussion of these results on out-of-sample forecasting. Specifically, we generate out-of-sample predictions by iteratively fitting our baseline probit models with lags of credit growth and of the ICRG measure to the available data up to $t-1$ and use this to predict the crisis probability at year $t$ (i.e., rolling regressions to forecast 1 year ahead).

The resulting out-of-sample AUC statistic is .62 for banking crises in EMEs, lower than the in-sample AUC but still significantly better than tossing a coin and in line with earlier work on predicting banking crises. ${ }^{21}$ Most importantly, we find that adding the ICRG measure considerably improves the out-of-sample performance; that is, the stability index clearly adds power. In a horse race, the ICRG-only model (political booms) even outperforms the credit-only model (credit booms) in EMEs, although the difference is not statistically significant. Like before, the joint model that accounts for both political booms and credit booms performs best, showing the highest AUC statistic. In advanced economies, we find that the ICRG measure has no predictive power, while the model with credit lags (credit booms only) performs well out of sample, with an AUC of .67. These results are in line with our in-sample findings and give assurance that political booms are useful for predicting crises 1 year in advance, but only in emerging economies.

In the appendix we also show out-of-sample results using contingency tables that are used to predict exact crisis years and also "danger zones" (namely, including the crisis year as well as 2 years before, as done in previous work). The model performs well overall, predicting $37 \%$ of EME exact crisis years. This number increases to $63 \%$ when we consider "danger zones." This result is robust to the choice of the model's classification threshold. Indeed, for any chosen threshold our model produces a higher FSR than the coin toss, up to more than doubling the forecast accuracy.

\section{E. A New Data Set on Government Popularity}

We built a novel data set of government popularity by collecting measures of government support directly from reputable polling organizations worldwide. Our data compilation contains high-quality time series of government approval polls (simply popularity henceforth) in 14 advanced economies and 16 emerging markets and as far back as possible. To the best of our knowledge there is no similar sample of polling data on

${ }^{21}$ In comparison, the out-of-sample AUC is .65 in Schularick and Taylor (2012) and .62 in Ward (2017, logit results). 
government support available for as many countries and as many periods. ${ }^{22}$ The appendix provides a detailed overview of the coverage, data sources, and definitions. ${ }^{23}$

These polling data are not sufficiently rich to replicate our previous stability index regressions, as polling time series are unavailable for many emerging markets during the 1980s and 1990s, the period with most EME crises. Specifically, the approval data cover only 7 of a total of 37 emerging market banking crises, compared to 33 crises that are covered by the ICRG stability index (see figs. D.1 and D.2 in the appendix for details). ${ }^{24}$

The new data set serves two purposes: first, to legitimate our interpretation of the stability index as government popularity and its increase as a political boom, and second, to zoom in on specific crises and track the evolution of popularity and the political environment surrounding those events. We develop these two points in the next two subsections.

\section{Government Stability Captures Government Popularity}

The stability index captures elements of both institutional quality and popular support, a combination that limits its interpretation as pure popularity, as we discussed. ${ }^{25}$ Here we show that changes in popularity are the most important determinant of changes in the stability index. In other words, perhaps not surprisingly, institutional quality tends to be a much more persistent component of the stability index. This helps justify our definition of political booms as increases in the stability index.

First, we find a high correlation between changes in the stability index and changes in government approval, as shown in the cross-section scatter plot of figure 5 , based on the full sample of 30 countries for which we

${ }^{22}$ Duch and Stevenson (2008) document that long time series on government approval or voting intentions are readily available only for a few advanced countries, such as the United States, the United Kingdom, or Germany, but scarce in most developing countries, especially prior to the mid-2000s. From 2005 onward, the Gallup World Poll covers government approval in more than 100 countries on an annual basis (see Guriev and Treisman 2016). Recently, Carlin et al. (2018) collected executive approval data for 18 Latin American countries.

${ }^{23}$ We are very thankful for the support of many people in this process and for their willingness to share data with us (their names are also listed in the appendix).

${ }_{24}$ The panel data set with government approval is also highly unbalanced, especially in EMEs, which is a challenge for any early warning model.

25 A second limitation is that the index is based on risk assessments by country experts, which could introduce a bias. The code book on the ICRG website states that "the ICRG staff collects political information and financial and economic data, converting these into risk points for each risk component on the basis of a consistent pattern of evaluation; the political risk assessments are made on the basis of subjective analysis of the available information" (PRS Group 2004, 2). 


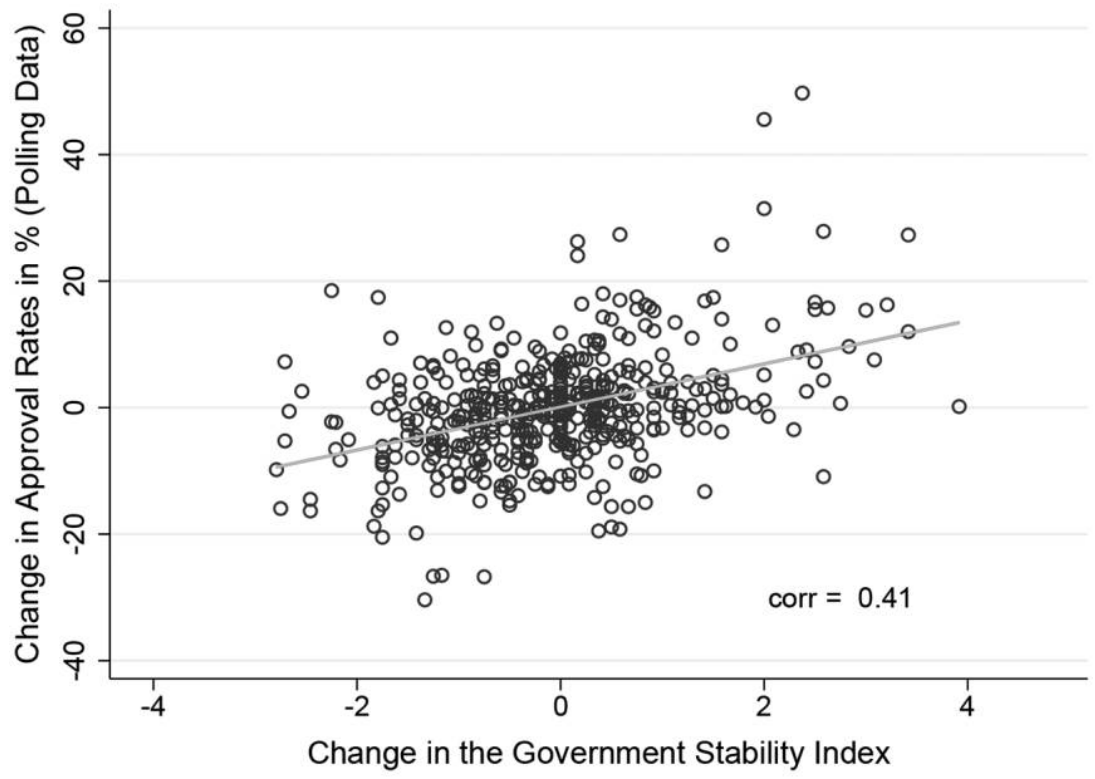

FIG. 5.-Changes in the stability index (from the ICRG) and popularity (from polls). A color version of this figure is available online.

have polling data. ${ }^{26}$ As an illustration, the appendix also includes the close co-movement of the two measures in four prominent countries in the sample: the United States, Germany, Argentina, and Russia.

Second, we find evidence that popularity is by far the main ingredient driving the stability index. Table 3 shows regression results using the stability index as a dependent variable and government approval (yearly poll averages) as an explanatory variable, in addition to a set of institutional and political controls (to account for political stability and legislative factors) and country fixed effects (to account for differences in the polling methodology across countries). Government approval is statistically significant both in levels and in first differences. Moreover, $20 \%$ of the large time variation in the stability index can be explained by changes in government approval alone. In contrast, institutional and political controls (cols. 3 and 4) have surprisingly little power in explaining the stability index and its movements. Put differently, popularity alone, measured directly through polling data, contributes more to the $R^{2}$ value in the regression than all of the other variables combined (cols. 5 and 6 ).

\footnotetext{
${ }^{26}$ The full sample correlation between the two measures is .41 and statistically significant. A similar result holds when using levels, with a correlation of .38. See the scatter plot shown in fig. E.1 of the appendix.
} 
Last but not least, we show that the stability index correlates with subsequent electoral outcomes, as one should expect. In particular, table E.1 in the appendix indicates that the lagged stability index is a good predictor for the probability of being reelected and negatively correlated with executive turnover as well as major government crises.

\section{The Evolution of Popularity around Specific Crisis Events}

Our novel polling data set allows us to scrutinize our key results with 12 case studies, namely, by tracking government approval around well-known crisis events for which poll data are available. These include the emerging market crises of Mexico 1995, Hong Kong 1997, the Philippines 1997, Russia 1998, and Uruguay 2002, as well as the advanced economy crises of Norway 1987, Finland 1991, Sweden 1991, Ireland 2007, the United Kingdom 2007, Spain 2008, and the United States 2008. As an illustration, we describe the political context of two of these crises below (the Philippines 1997, an emerging economy, and Sweden 1991, an advanced economy) and then summarize the evolution of popularity for the other 10 financial crises in the appendix. The main takeaway is that our key stylized fact is confirmed: in all cases, government approval increases markedly prior to crises in emerging markets, but not in advanced economies. Moreover, the figures illustrate that governments are often replaced after a crisis and that, around crises, the poll-based government approval series co-move rather closely with the ICRG stability index.

Figure 6 focuses on the Philippines, where President Ramos enjoyed increasing public support between the end of 1995 and mid-1997, a period with strong economic and credit growth. ${ }^{27}$ Loans to the private sector expanded most in 1995 and 1996 (with growth rates of more than $40 \%$ per year), and this was partly a consequence of the financial deregulation enacted after Ramos took office in 1992 (see Corsetti, Pesenti, and Roubini 1999). In parallel, Ramos's popularity nearly doubled, as shown by the polling data, as well as the ICRG stability index. At the peak of this political and economic boom, and less than a year from the next presidential elections, President Ramos prominently declared that "the Philippines is no longer trapped in its old cycle of boom and bust. . . That past is now over, and a great era dawns upon us." ${ }^{28}$ Yet, the crisis

${ }^{27}$ Press reports at the time indicate that President Ramos was highly concerned with his low approval ratings in 1995, taking measures to boost the economy in his final 2 years in office. His press secretary Hector Villanueva explained that "the president's policy decisions are, well, not really influenced, but are guided by his popularity performance" ("Ramos Unpopular at Home," United Press International, February 22, 1996).

28 See his state of the union address of July 1997: https://www.officialgazette.gov.ph /1997/07/28/fidel-v-ramos-sixth-state-of-the-nation-address-july-28-1997. 


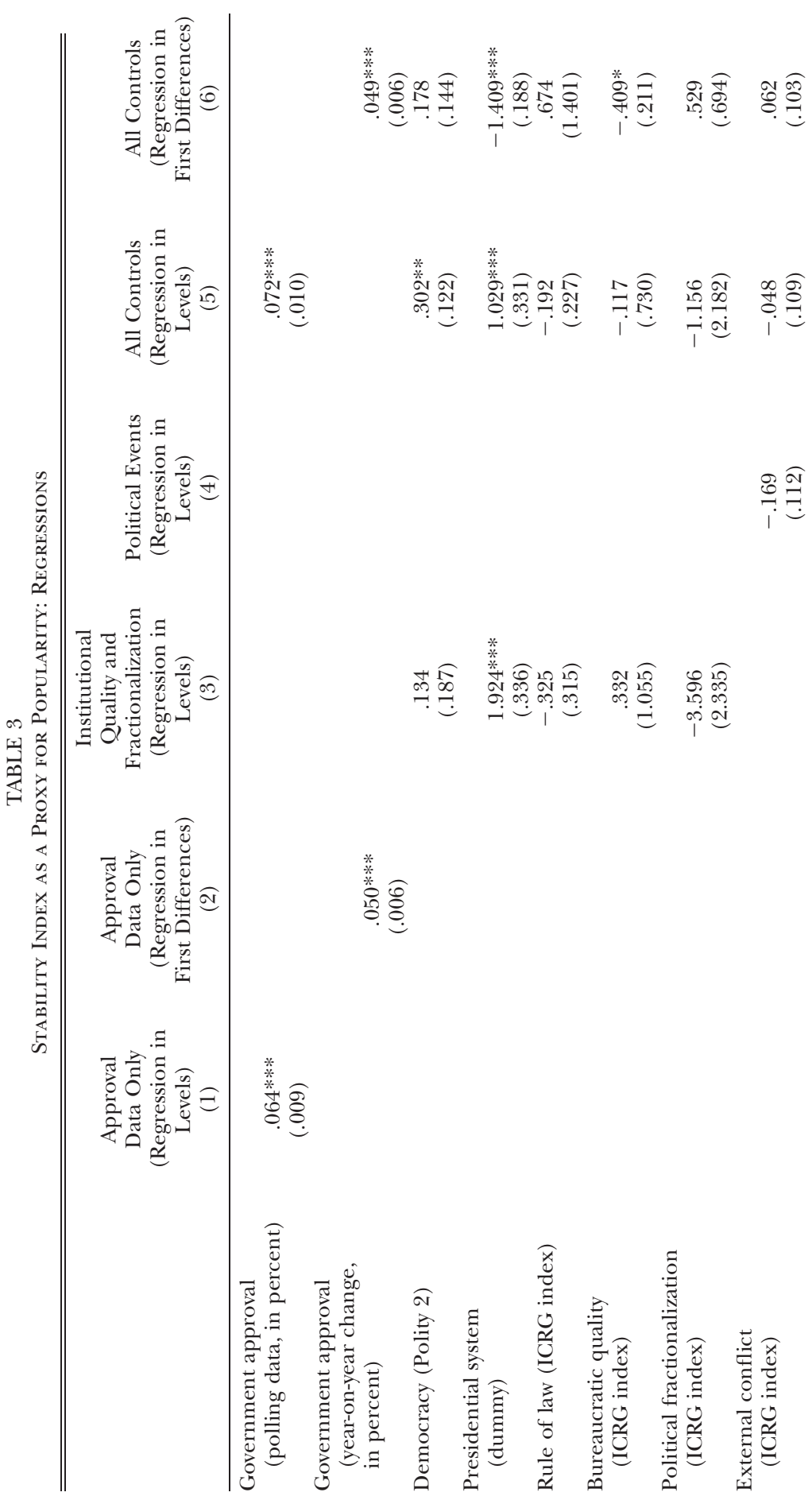

530

This content downloaded from 035.176.047.006 on February 24, 2020 11:39:28 AM 


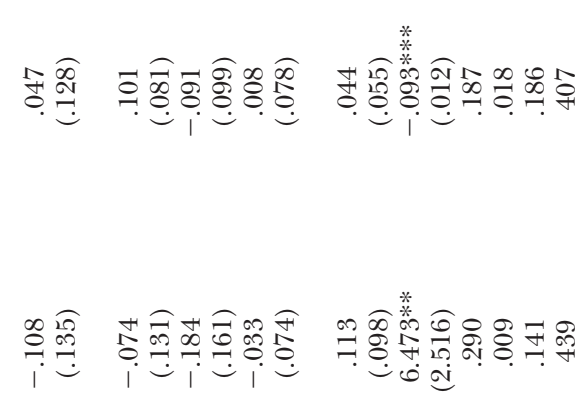

0
0
0
0
0
0
$\frac{5}{5}$
$\frac{5}{2}$
0
0
0
0
0

苞

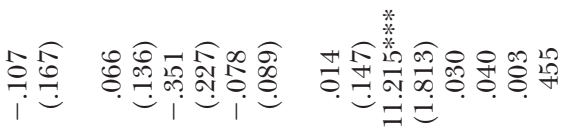

है 远

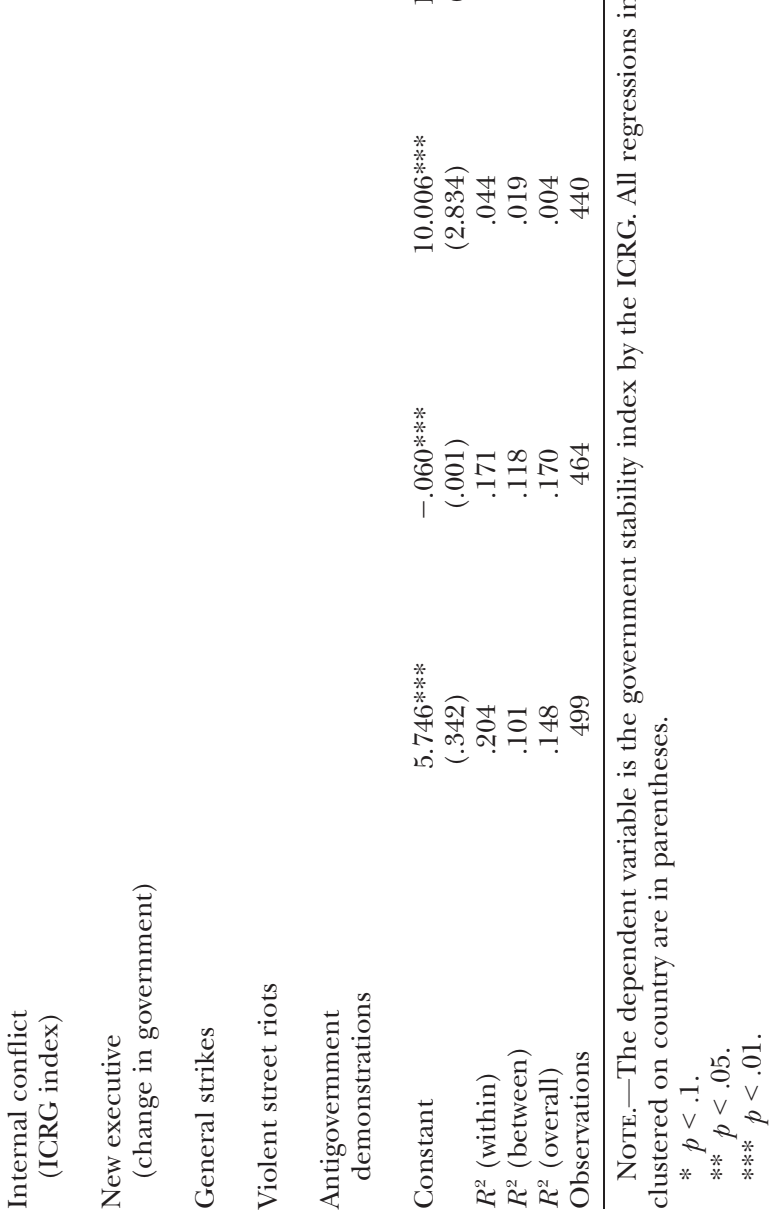

531

This content downloaded from 035.176.047.006 on February 24, 2020 11:39:28 AM 


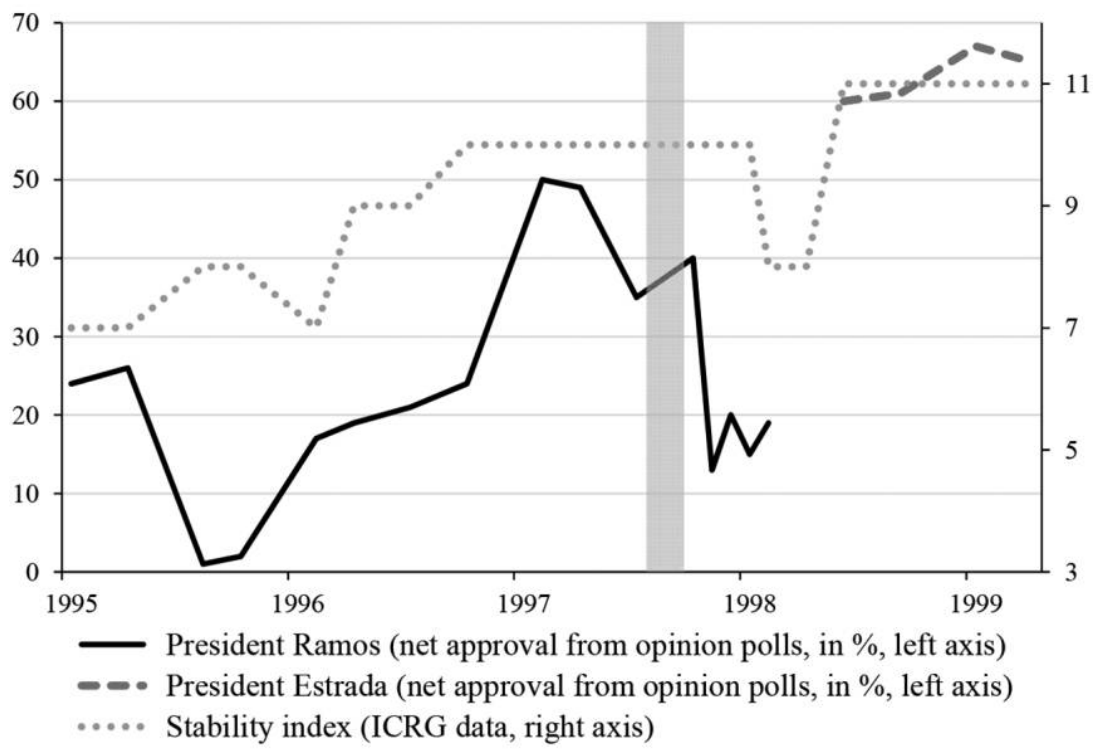

FIG. 6.-Government popularity surrounding the 1997 crisis in the Philippines.

broke out just 2 months later, Ramos's popularity collapsed, and the opposition candidate Joseph Estrada won a landslide victory in May 1998.

The political environment looks very different in precrisis Sweden, where the Carlson government saw a gradual decline in voter support (from $45 \%$ to $30 \%$ ) in the 4 years preceding the crash of 1991 (the stability index shows a very similar trend). After the crisis, the ruling Social Democrats lost the election and a new center-right coalition came to power (fig. 7).

\section{Model}

We have shown that political booms predict crises above and beyond credit booms, but only in emerging economies. The simple model we present now illustrates a potential channel connecting political booms with financial crises. As we show, the mechanism we propose operates mostly in emerging economies and is thus consistent with the evidence above.

In the model, governments may try to maintain/improve popularity by avoiding regulatory actions to control credit booms, thereby increasing the risk of a crisis. Our goal is to explain the emerging market phenomenon of political booms gone bust without imposing ex ante intrinsic economic differences between emerging and advanced economies, 


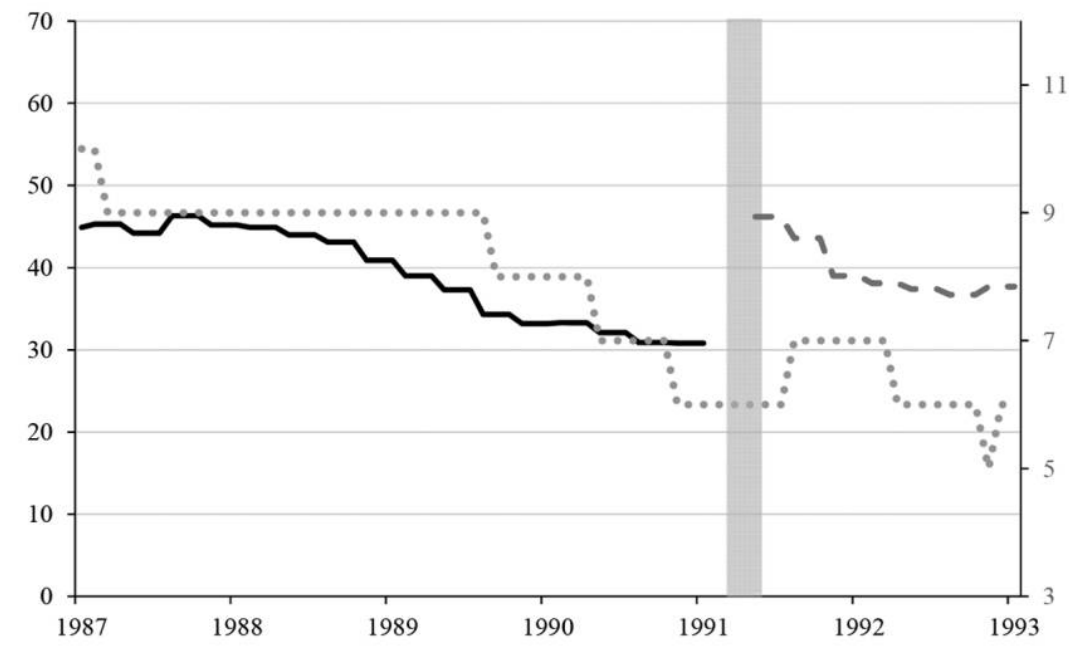

_ Carlson center-left government (voter support from opinion polls, in \%, left axis)

- Bildt center-right government (voter support from opinion polls, in \%, left axis)

$\ldots$ Stability index (ICRG data, right axis)

FIG. 7.-Government popularity surrounding the 1991 crisis in Sweden.

but instead relying on political motivations alone and exploring how those motivations might differ across countries.

The model predicts that (i) countries characterized by more volatile, and on average lower, government popularity are more likely to ride booms; (ii) regulation (or lack thereof) is a key policy feature that distinguishes emerging and advanced economies during credit booms. Lastly, we provide evidence for these two model predictions.

\section{A. Environment}

The economy is composed of households (or voters) and a government. A credit boom generates economic gains $\Pi$ for households, but may generate larger economic losses $X>\Pi$ if it ends in a crisis. The boom can be good $(g)$ or bad $(b)$. A good boom is sustained by an increase in productivity and ends in crisis with an exogenous probability $\eta$. A bad boom is sustained by speculation and without regulation may bust, causing a crisis with a higher probability $\hat{\eta}=q+\eta(1-q)>\eta$, where $q$ is the additional chance that a bad boom ends in a crisis relative to the good boom. We assume that regulation reduces the economic gains of a credit boom only by an $\varepsilon>0$, while it reduces the probability of crisis from $\hat{\eta}$ to $\eta$ in a bad boom, not affecting the probability $\eta$ of crisis in a good boom. We 
assume that regulation is always optimal in a bad boom [i.e., $(\hat{\eta}-\eta) X>$ $\varepsilon]$ and never optimal in good boom, as $\varepsilon>0 .^{29}$

Given this first-best response for each type of boom, we denote regulation as $\hat{b}$ (the optimal policy for booms $b$ ) and no regulation, namely riding the boom, as $\hat{g}$ (the optimal policy for booms $g$ ).

There are two types of governments: good $(G)$ and bad $(B)$. The government knows its own type and we assume good governments are more likely to generate good booms than bad governments; that is,

$$
p_{G} \equiv \operatorname{Pr}(g \mid G)>p_{B} \equiv \operatorname{Pr}(g \mid B) .
$$

We assume that governments observe the type of the boom, while households do not, although this strong assumption can be relaxed without changing our results qualitatively. ${ }^{30}$ Moreover, good governments always act optimally (they regulate a boom if and only if it is bad), which allows us to focus just on the strategy of bad governments. ${ }^{31}$

Government payoffs increase in two factors: its reputation level $\phi$ ( $r e-$ main in office motivation) and a policy reward parameter $\rho$ (enact the right policy motivation). The reputation level $\phi$ is the household-assessed probability that the government is $\operatorname{good} \phi \equiv \operatorname{Pr}(G),{ }^{32}$ while the reward parameter $\rho$ measures the magnitude of the policy motivation relative to the office motivation. We assume $\rho>0$, which implies that the government's interests are aligned with those of the voters and that the government benefits from enacting policies that are optimal given the nature of the booms.

This is a single-period economy with the following timing within the period: Nature draws the government type $\{B, G\}$. The government observes a boom of type $s \in\{b, g\}$, which depends stochastically on the government's type. The government decides whether to regulate or ride the boom $r \in\{\hat{b}, \hat{g}\}$. Households observe this regulation decision and subsequently a crisis or no crisis $\mathrm{cr} \in\{\mathrm{C}, \mathrm{NC}\}$, updating their beliefs about the government's type. Finally, the government receives a payoff that

\footnotetext{
${ }^{29}$ The welfare gain from riding a bad boom is $\Pi-\hat{\eta} X$ and from riding a good boom $\Pi-\eta X$. The welfare gain from regulating any boom is $\Pi-\varepsilon-\eta X$.

${ }^{30}$ What matters for the model to work is that the government has at least some additional information about the nature of the boom and then the likelihood of a crisis.

${ }^{31}$ This assumption is expositionally convenient to maintain a unique outcome. Allowing good governments to decide whether or not to regulate generically expands the set of equilibria. As discussed in Fudenberg and Levine (1998), taking the optimal action is an evolutionarily stable strategy for good governments. We could also justify this assumption by imposing that good governments face larger costs from crises (or that they have a higher discount factor), in which case they would optimally choose to regulate bad booms more frequently than bad governments.

${ }^{32}$ In this simple setup we do not model elections and simply interpret the incumbents' payoff as the reelection chance. This is true in a model in which the incumbent faces an opponent with the type drawn from an ex ante distribution, and then average reputation. See the appendix for an application of this reelection chance modeling.
} 
depends on its updated reputation $\phi_{r, \mathrm{cr}}(\phi)$, a function of its current reputation $\phi$, its regulation decision $(r \in\{\hat{g}, \hat{b}\})$, and the crisis state $(\mathrm{cr} \in\{\mathrm{C}, \mathrm{NC}\})$. The strategy $\sigma_{B}(r \mid s)$ is defined as $B$ 's chance of implementing policy $r$ in state $s$; thus $B$ 's expected payoffs in each state are

$$
\begin{aligned}
& u\left(\sigma_{B}(. \mid g)\right)=\sigma_{B}(\hat{g} \mid g)\left[\rho+E\left(\phi_{\hat{g}} \mid g\right)\right]+\sigma_{B}(\hat{b} \mid g)\left[\phi_{\hat{b}}\right], \\
& u\left(\sigma_{B}(. \mid b)\right)=\sigma_{B}(\hat{g} \mid b)\left[E\left(\phi_{\hat{g}} \mid b\right)\right]+\sigma_{B}(\hat{b} \mid b)\left[\rho+\phi_{\hat{b}}\right],
\end{aligned}
$$

where $E\left(\phi_{\hat{g}} \mid g\right)$ is the expected reputation from riding a good boom and $\phi_{b}$ is the (expected) reputation from regulating a bad boom. ${ }^{33}$

\section{B. Equilibrium}

A perfect Bayesian equilibrium consists of regulation strategies $\sigma_{B}=$ $\left\{\sigma_{B}(. \mid g), \sigma_{B}(. \mid b)\right\}$ and updated reputation $\phi_{r, \mathrm{cr}}$ such that (i) $B$ maximizes utility, (ii) Bayes's rule is used to update reputation, and (iii) households' beliefs about strategy $\sigma_{B}$ are correct.

Proposition 1. In any equilibrium, $B$ never regulates a good boom: $\sigma_{B}(\hat{g} \mid g)=1$.

This result means there is no distortion from the optimal policy during good booms. Since $\sigma_{B}(\hat{g} \mid g)=1$, then $\sigma:=\sigma_{B}(\hat{g} \mid b)$ is effectively the only strategic choice variable, that is, the probability of "riding" bad booms. We call $\sigma^{*} \in[0,1]$ the amount of distortion in equilibrium, and we say that the policy is distorted if $\sigma^{*}>0$. All proofs can be found in the appendix.

Proposition 2. The equilibrium exists and is unique. If $\phi \in(0,1)$, the equilibrium displays policy distortion $\sigma^{*}>0$ for a positive interval $\rho \in[0, \bar{\rho})$.

The intuition of this proposition is illustrated in figure 8 , where we show the net reputational gain from riding a bad boom, $Z(\sigma, \phi)=$ $E\left(\phi_{\hat{g}} \mid b\right)(\sigma)-\phi_{\hat{b}}(\sigma)$, and compare it to $\rho$. From equation (2) it is clear that bad governments ride bad booms if and only if $Z(0, \phi):=\bar{\rho}>\rho$.

Note that $Z(\sigma, \phi)$ is strictly decreasing in $\sigma$, with $Z(0, \phi)>0$ and $Z(1, \phi)<0$, which means that the net benefits of riding a bad boom shrink when it becomes more likely that bad governments ride bad booms: when bad governments never ride bad booms, then riding is a good signal for the public, equivalent to observing good booms, but when bad governments ride bad booms more frequently, riding is no longer a precise

\footnotetext{
33 The expectation is taken over the probability of facing a crisis or not. Since conditional on regulation there is no further updating conditional on crisis, the expectation term does not apply in this case. This is just a special result from assuming that upon regulation both booms have the same probability $\eta$ of ending up in a crisis.
} 


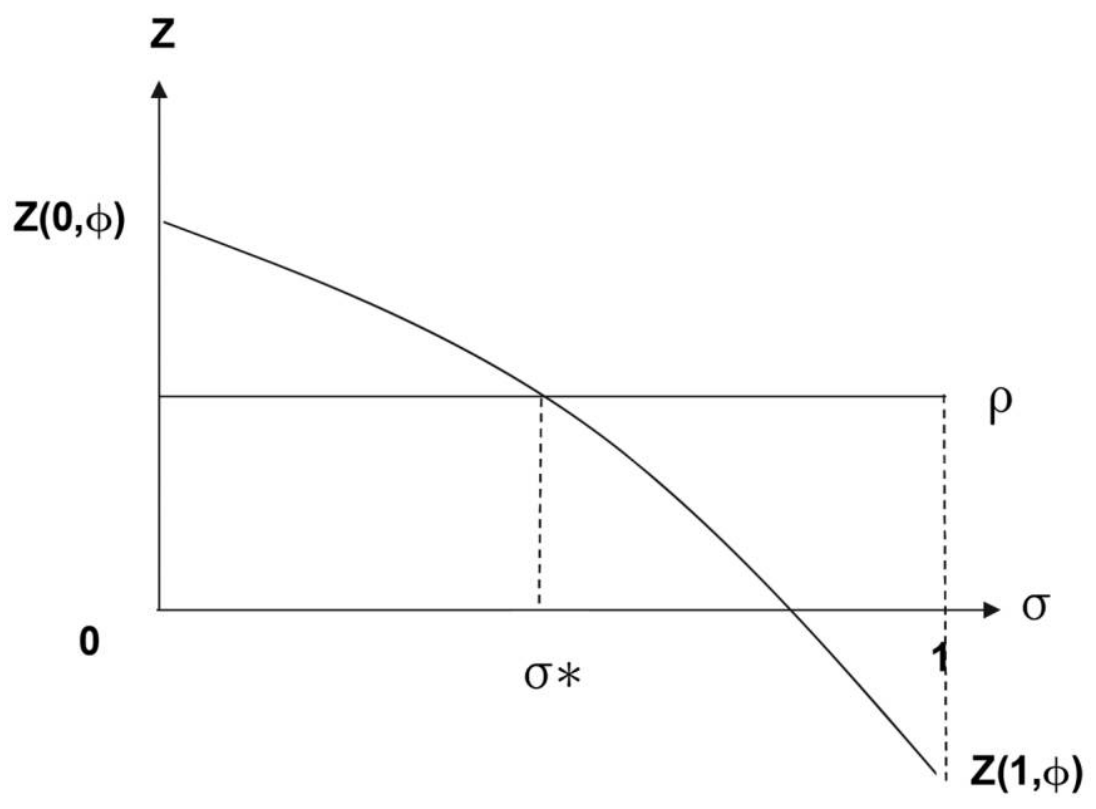

FIG. 8.-Properties of $Z(\sigma, \phi)$.

signal of a good boom. ${ }^{34}$ Thus in this case regulation is politically costly: reputation decreases with regulation.

Inspecting figure 8 , it is evident that an equilibrium exists and is unique. Intuitively, a larger policy motivation parameter $\rho$ increases the expected gains from avoiding crises, which induces more regulation and lower distortions. It is also clear that, all else equal, as $Z(0, \phi)$ increases, distortions $\sigma^{*}$ increase as well.

Figure 9 tracks the critical value $\bar{\rho}:=Z(0, \phi)$ for different reputation levels $\phi$, showing a nonmonotonicity. The following comparative statics on the distortion probability $\sigma^{*}$ are evident from the figure but are also proved in the appendix: (i) No government rides a bad boom if there are no reputational gains, namely, either if types are the same $p_{B}=p_{G}$ or if there is only one type, $\phi \in\{0,1\}$. (ii) Riding bad booms is more likely when reputation is intermediate $\phi \in(\underline{\phi}, \bar{\phi})$; that is, when the government's type is very uncertain there is more room for governments

\footnotetext{
${ }^{34}$ Several models of reputation-concerned governments have been proposed in the literature. Our setting, however, captures our key finding linking popularity surges before financial crises only in certain countries. Models of reputation in line with the seminar work of Kreps and Wilson (1982), for example, would suggest that governments "misbehave" (i.e., prefer to face the probability of a crisis rather than making efforts to prevent it) only when their reputation is large. This prediction, however, contradicts our empirical findings. Here we allow the data to discipline our modeling choices.
} 


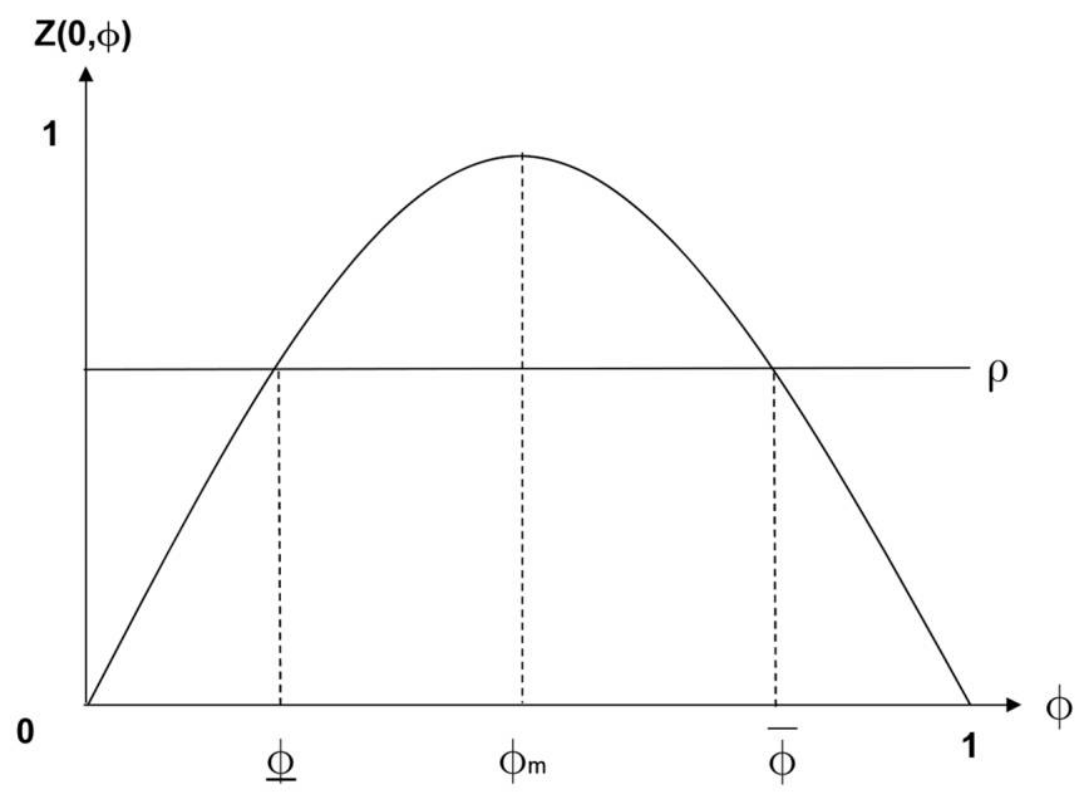

FIG. 9.-Governments with intermediate reputation distort more.

to change public opinion with their actions. (iii) The larger the $p_{G}$ and the lower the $p_{B}$, that is, the larger the variance of political types, the higher the incentives to ride a bad boom, as the popularity loss from regulation following the optimal policy is greater.

\section{Mapping the Model to the Data}

We now show that this model is consistent with the findings in the empirical section. First, we demonstrate that the model implies that political booms predict financial crises when potential concerns are large. Then, we discuss why emerging markets are more likely to present larger popularity concerns, thus making political booms better predictors of financial crises in those countries.

\section{Political Booms Can Predict Financial Crises}

In the model we capture the change of popularity by the interim reputation updating after regulation (or lack thereof) is observed but before a crisis (or lack thereof) is.

The interim updated reputation, conditional on riding a boom $(\hat{g})$ and conditional on regulating a boom $(\hat{b})$ is 


$$
\begin{aligned}
\phi_{\hat{g}} & :=\frac{\phi p_{G}}{\phi p_{G}+(1-\phi)\left[p_{B}+\left(1-p_{B}\right) \sigma^{*}\right]}, \\
\phi_{\hat{b}} & :=\frac{\phi\left(1-p_{G}\right)}{\phi\left(1-p_{G}\right)+(1-\phi)\left[\left(1-p_{B}\right)\left(1-\sigma^{*}\right)\right]} .
\end{aligned}
$$

The next proposition shows that interim reputation declines upon regulation.

Proposition 3. Conditional on observing regulation (riding), reputation declines (increases), namely,

$$
\phi_{\hat{g}}>\phi>\phi_{\hat{b}} \text {. }
$$

The ex ante probabilities of observing these interim changes in popularity are determined by the ex ante probabilities of observing regulation (or lack thereof),

$$
\begin{aligned}
& \operatorname{Pr}\left(\phi_{\hat{b}}\right)=\phi\left(1-p_{G}\right)+(1-\phi)\left(1-p_{B}\right)\left(1-\sigma^{*}\right), \\
& \operatorname{Pr}\left(\phi_{\hat{g}}\right)=\phi p_{G}+(1-\phi)\left[p_{B}+\left(1-p_{B}\right) \sigma^{*}\right] .
\end{aligned}
$$

Thus, the likelihood of a crisis conditional on observing a decline in popularity (i.e., conditional on regulation) is

$$
\operatorname{Pr}\left(C \mid \phi_{\hat{b}}\right)=\frac{\operatorname{Pr}\left(C, \phi_{\hat{b}}\right)}{\operatorname{Pr}\left(\phi_{\hat{b}}\right)}=\eta .
$$

Similarly, the likelihood of a crisis conditional on observing an increase in popularity (i.e., conditional on no regulation) is

$\operatorname{Pr}\left(C \mid \phi_{\hat{g}}\right)=\frac{\phi p_{G} \eta+(1-\phi) p_{B} \eta+(1-\phi)\left(1-p_{B}\right) \sigma^{*} \hat{\eta}}{\phi p_{G}+(1-\phi)\left[p_{B}+\left(1-p_{B}\right) \sigma^{*}\right]}=\eta+\frac{\sigma^{*} \Omega}{\operatorname{Pr}\left(\phi_{\hat{g}}\right)}$,

where

$$
\Omega:=(1-\phi)\left(1-p_{B}\right)[q(1-\eta)]
$$

Equations (4) and (3) show a larger chance of crisis after observing an increase in reputation from $\phi$ to $\phi_{\hat{g}}$ relative to observing a decrease from $\phi$ to $\phi_{b}$. In essence, bad governments riding bad booms with positive probability, $\sigma^{*}>0$, is a necessary and sufficient condition for surges in popularity predicting crises. Importantly, a larger distortion probability $\sigma^{*}$ implies higher predictive power of a political boom. That is, $\operatorname{Pr}\left(C \mid \phi_{\hat{g}}\right)-$ $\operatorname{Pr}\left(C \mid \phi_{\hat{b}}\right)$ is larger.

In the appendix we simulate this model as a full-fledged repeated game. We assume an exogenous fraction $\phi_{0}$ of good governments in the pool of politicians. If an incumbent earns a reputation $\phi<\phi_{0}$ she is replaced by 
another government with $\phi=\phi_{0}$ from the pool, and so forth. ${ }^{35}$ Then we run regressions as we did with the empirical data and we obtain the same qualitative result; namely, in the absence of potential popularity gains, changes in popularity cannot predict crises.

In the data we cannot directly observe whether governments have or have not enacted regulations targeted and designed to avoid specific crises, but we can use the model to interpret an increase in reputation as reflecting looser financial regulations and a decline in reputation as reflecting tighter financial regulations. In spite of the difficulties in capturing the effect of regulations (we do not observe crises that were avoided by successful regulation), in the appendix we show some evidence that regulation (or the absence of it) seems to be an important link between surges in popularity and the likelihood of crises in emerging markets. First, we show that there is a negative correlation between regulation and government popularity. Second, we document (i) that emerging market crises are usually preceded by loose regulation and (ii) that emerging economies regulate less, relative to trend, during credit booms that end in a financial crisis than during credit booms that end without crises (the opposite is true for advanced economies).

\section{Why Only in Emerging Markets?}

Here we argue that potential popularity gains are stronger in emerging markets because the reputation of their governments is intermediate [from the model standpoint this is $\phi \in(\phi, \bar{\phi})$ and $\sigma^{*}>0$ ]. In contrast, in advanced economies average popularity is higher (from the model standpoint a smaller $\sigma^{*}$ such that the difference between eqq. [4] and [3] is not large enough to predict crises). ${ }^{36}$

There is a key feature of intermediate reputation levels that allows us to check whether an environment with high distortions is typical in emerging economies: volatility of popularity. All else equal, beliefs vary more when the reputation prior is intermediate. To see this notice that the Bayesian updating variation is

$$
\phi_{\hat{g}}-\phi_{\hat{b}}=\phi(1-\phi) \frac{p_{G}-p_{B}-\left(1-p_{B}\right) \sigma^{*}}{\operatorname{Pr}(\hat{g}) \operatorname{Pr}(\hat{b})},
$$

${ }^{35}$ In our single-period setting the initial reputation of a government, $\phi$, coincides with the fraction of good governments in the pool of politicians, $\phi_{0}$. In the repeated game, the fraction of good governments in the pool of politicians only determines the initial reputation of new governments.

${ }^{36}$ In particular, if the reputation is relatively high such as $\phi>\bar{\phi}$, then $\sigma^{*}=0$, the probability of a crisis is $\eta$, and the increase in popularity does not help to predict a crisis at all. 
where $\phi(1-\phi)$ is the variance of popularity, which is larger for intermediate levels of $\phi .^{37}$

Empirically, the popularity of governments in emerging countries is indeed more volatile: the standard deviation of our stability index is 4.04 in emerging economies and 2.47 for advanced economies, with the difference being statistically significant at a $99 \%$ confidence level. Similarly, the standard deviation of our new data series on government approval is $21.2 \%$ in emerging economies and $13.1 \%$ for advanced economies, also statistically significant at a $99 \%$ confidence level.

A second piece of evidence suggests that governments in emerging economies have intermediate reputation levels: (i) reputation cannot be too low as our database mainly includes democratic countries with regular turnover and thus reputation is almost always truncated below, and (ii) reputation in advanced economies is higher. The average stability index, for example, is 8.22 in advanced economies and 7.57 in emerging economies, with the difference being statistically significant at the $99 \%$ confidence level. ${ }^{38}$ Finally, to further corroborate this finding the appendix shows that, even among emerging markets alone, political booms predict crises better in countries with lower levels of popularity.

\section{Conclusions}

Financial crises are often credit booms gone wrong, in both developed and emerging markets. In this paper we show that in emerging economies, financial crises are also political booms gone wrong. This new fact helps us to understand why credit booms may end up in crises. Our model proposes an explanation consistent with this finding and other features of the data: striving to build popularity, governments may avoid corrective measures during credit booms, which results in higher risk that booms go bust. In emerging markets, governments have more to gain from riding credit booms, because the popularity of politicians in these countries is more volatile compared to advanced economies. This key difference also explains why most emerging market crises were preceded by inaction or even deregulation, rather than regulation.

Our paper suggests that financial crises may be the result not only of exogenous fundamental economic differences across countries, as often proposed in the literature, but also of perverse incentives within political

\footnotetext{
${ }^{37}$ Note that more volatile popularity in our setting is not the result of greater heterogeneity in the quality of governments but rather a property of Bayesian updating for intermediate priors about the quality of governments. In other words, given a signal, reputation changes more when the prior is neither too low nor too high.

${ }^{38}$ Before 1990 this difference was even larger, with an average popularity index of 8.43 in advanced economies and 6.00 in emerging economies, also a statistically significant difference.
} 
systems. This calls for a dynamic theory of political-financial traps: a country that holds its politicians in low regard is more subject to crises and economic volatility, as the political gains from "gambling for redemption" strategies are larger. This, in turn, makes high-risk policies more likely and keeps the average reputation of politicians low, a vicious circle.

We have studied how political incentives affect the probability of financial crises. The main insight is that credit booms in emerging markets are particularly dangerous when accompanied by a political boom. A related question for future work is how politically motivated governments can "manufacture" credit booms and how political incentives may influence the evolution of those credit booms in the first place.

\section{References}

Acemoglu, Daron, Simon Johnson, and James A. Robinson. 2001. "The Colonial Origins of Comparative Development: An Empirical Investigation.” A.E.R. 91:1369-1401.

Ales, Laurence, Pricila Maziero, and Pierre Yared. 2014. "A Theory of Political and Economic Cycles." L. Econ. Theorv 153:224-51.

Alfaro, Laura, Sebnem Kalemli-Ozcan, and Vadym Volosovych. 2008. "Why Doesn't Capital Flow from Rich to Poor Countries? An Empirical Investigation." Rev. Econ. and Statis. 90 (2): 347-68.

Segalotto, Jean-François, Marco Arnone, and Bernard J. Laurens. 2006. "Measures of Central Bank Autonomy: Empirical Evidence for OECD, Developing, and Emerging Market Economies." Working Paper no. 06/228, IMF, Washington, DC.

Azzimonti, Marina. 2011. "Barriers to Investment in Polarized Societies." A.E.R. 101 (5): 2182-2204.

Banks, Arthur, and Kenneth Wilson. 2013. "Cross National Time-Series Data Archive." https://www.cntsdata.com.

Bianchi, Javier, and Enrique Mendoza. 2012. "Overborrowing, Financial Crises and 'Macro-prudential' Policy." Working Paper no. 16091 (September), NBER, Cambridge, MA.

Brender, Adi, and Allan Drazen. 2008. "How Do Budget Deficits and Economic Growth Affect Reelection Prospects? Evidence from a Large Panel of Countries." A.E.R. 98 (5): 2203-20.

Buendia, Jorge. 1996. "Economic Reform, Public Opinion, and Presidential Approval in Mexico, 1988-1993." Comparative Polit. Studies 29 (5): 566-91.

Calomiris, Charles W., and Stephen H. Haber. 2014. Fragile by Design: The Political Origins of Banking Crises and Scarce Credit. Princeton, NJ: Princeton Univ. Press.

Calvo, Guillermo A., Alejandro Izquierdo, and Luis-Fernando Mejía. 2008. "Systemic Sudden Stops: The Relevance of Balance-Sheet Effects and Financial Integration.” Working Paper no. 14026 (May), NBER, Cambridge, MA.

Calvo, Guillermo A., and Enrique G. Mendoza. 1996. "Mexico's Balance-ofPayments Crisis: A Chronicle of a Death Foretold." I. Internat. Econ. 41 (3-4): 235-64.

Carlin, Ryan E., Jonathan Hartlyn, Timothy Hellwig, Gregory J. Love, Cecilia Martinez-Gallardo, and Matthew M. Singer. 2018. "Public Support for Latin American Presidents: The Cyclical Model in Comparative Perspective.” Res. and Polit. 5 (3): 1-8. 
Catao, Luis A. V., and Gian Maria Milesi-Ferretti. 2014. "External Liabilities and Crises." L. Internat. Econ. 94 (1): 18-32.

Chang, Roberto. 2001. "Commitment, Coordination Failures, and Delayed Reforms." I. Monetarv Econ. 47 (1): 123-44.

- 2007. "Financial Crises and Political Crises." L. Monetary Econ. 54 (8): 2409-20.

Claessens, Stijn, M. Ayhan Kose, and Marco Terrones. 2011. "Financial Cycles: What? How? When?" Working Paper no. 11/76, IMF, Washington, DC.

Corsetti, Giancarlo, Paolo Pesenti, and Nouriel Roubini. 1999. "What Caused the Asian Currency and Financial Crisis?" Iapan and World Econ. 11 (3): 305-73.

Drazen, Allan. 2000. "The Political Business Cycle after 25 Years." NBER Macroeconomics Ann. 15:75-117.

Duch, Raymond, and Randolph Stevenson. 2008. The Economic Vote: How Political and Economic Institutions Condition Election Results. Cambridge: Cambridge Univ. Press.

Fernandez-Villaverde, Jesus, Luis Garicano, and Tano Santos. 2013. "Political Credit Cycles: The Case of the Eurozone." L. Econ. Perspectives 27 (3): 145-66.

Forbes, Kristin J., and Francis E. Warnock. 2012. "Capital Flow Waves: Surges, Stops, Flight, and Retrenchment." L. Internat. Econ. 88 (2): 235-51.

Fudenberg, Drew, and David K. Levine. 1998. The Theory of Learning in Games. Cambridge, MA: MIT Press.

Funke, Manuel, Moritz Schularick, and Christoph Trebesch. 2016. "Going to Extremes: Politics after Financial Crises, 1870-2014." European Econ. Rev. 88:22760.

Gelos, R. Gaston, and Shang-Jin Wei. 2005. "Transparency and International Portfolio Holdings." I. Finance 60 (6): 2987-3020.

Goldstein, Morris, Graciela Kaminsky, and Carmen Reinhart. 2000. Assessing Financial Vulnerability: An Early Warning System for Emerging Markets. Washington, DC: Peterson Inst. Internat. Econ.

Gorton, Gary, and Guillermo Ordoñez. 2014. "Collateral Crises." A.E.R. 104 (2): $343-78$

2016. "Good Booms, Bad Booms.” Working Paper no. 22008 (February), NBER, Cambridge, MA.

Gourinchas, Pierre-Olivier, and Maurice Obstfeld. 2012. "Stories of the Twentieth Century for the Twenty-First." American Econ. I.: Macroeconomics 4 (1): 226-65.

Green, David M., and John A. Swets. 1966. Signal Detection Theory and Psychophysics. New York: Wiley and Sons.

Guriev, Sergei M., and Daniel Treisman. 2016. "What Makes Governments Popular?” Discussion Paper no. DP11460 (August), CEPR, London.

Haber, Stephen. 2005. "Mexico's Experiments with Bank Privatization and Liberalization, 1991-2003." L. Banking and Finance 29 (8-9): 2325-53.

International Monetary Fund. 2000. "Financial Sector Crisis and Restructuring: Lessons from Asia." Occasional Paper no. 188, IMF, Washington, DC.

Kessler, Timothy P. 1998. "Political Capital: Mexican Financial Policy under Salinas." World Polit. 51 (1): 36-66.

Kreps, David M., and Robert Wilson. 1982. "Reputation and Imperfect Information." I. Econ. Theory 27:253-79.

Laeven, Luc, and Fabian Valencia. 2010. "Resolution of Banking Crises: The Good, the Bad, and the Ugly." Working Paper no. 10/146, IMF, Washington, DC.

2012. "Systemic Banking Crises Database: An Update." Working Paper no. 12/163, IMF, Washington, DC. 
Lindbeck, Assar. 1976. "Stabilization Policy in Open Economies with Endogenous Politicians.” A.E.R. 66:1-19.

Maskin, Eric, and Jean Tirole. 2004. "The Politician and the Judge: Accountability in Government." A.E.R. 94 (4): 1034-54.

McCarty, Nolan, Keith T. Poole, and Howard Rosenthal. 2013. Political Bubbles: Financial Crises and the Failure of American Democracy. Princeton, NJ: Princeton Univ. Press.

Mendoza, Enrique G., and Marco E. Terrones. 2012. "An Anatomy of Credit Booms and Their Demise.” Working Paper no. 18379 (September), NBER, Cambridge, MA.

Nordhaus, William D. 1975. "The Political Business Cycle." Rev. Econ. Studies 42:169-90.

Persson, Torsten, and Guido Tabellini. 2000. Political Economics: Explaining Economic Policy. Cambridge, MA: MIT Press.

Peterson, William W., Theodore G. Birdsall, and William C. Fox. 1954. "The Theory of Signal Detectability." Transactions IRE Professional Group Information Theory 4 (4): 171-212.

PRS Group. 2004. ICRG Methodology. https://www.prsgroup.com/wp-content /uploads/2012/11/icrgmethodology.pdf.

Radelet, Steven, and Jeffrey Sachs. 1998. "The Onset of the East Asian Financial Crisis.” Working Paper no. 6680 (August), NBER, Cambridge, MA.

Ranciere, Romain, Aaron Tornell, and Frank Westermann. 2008. "Systemic Crises and Growth." O.J.E. 123 (1): 359-406.

Reinhart, Carmen M., and Vincent R. Reinhart. 2010. "After the Fall.” Working Paper no. 16334 (September), NBER, Cambridge, MA.

Reinhart, Carmen M., Vincent R. Reinhart, and Chistoph Trebesch. 2017. "Capital Flow Cycles: A Long, Global View.” Manuscript, Kennedy School, Harvard Univ.

Reinhart, Carmen M., and Kenneth S. Rogoff. 2009. "The Aftermath of Financial Crises." A.E.R. 99 (2): 466-72.

Reinhart, Carmen M., Kenneth S. Rogoff, and Miguel Savastano. 2003. "Debt Intolerance." Brookings Papers Econ. Activity 34 (1): 1-74.

Rogoff, Kenneth S. 1990. "Equilibrium Political Budget Cycles." A.E.R. 80:21-36.

Rogoff, Kenneth S., and Anne Sibert. 1988. "Elections and Macroeconomic Policy Cycles." Rev. Econ. Studies 55:1-16.

Schuknecht, Ludger. 1996. "Political Business Cycles in Developing Countries." Kvklos 49:155-70.

Schularick, Moritz, and Alan M. Taylor. 2012. "Credit Booms Gone Bust: Monetary Policy, Leverage Cycles, and Financial Crises, 1870-2008.” A.E.R. 102 (2): 1029-61.

Shi, Min, and Jakob Svensson. 2006. "Political Business Cycles in Developed and Developing Countries.” L. Public Econ. 90 (8-9): 1367-89.

Tornell, Aaron, and Philip R. Lane. 1999. "The Voracity Effect." A.E.R. 89 (1): $22-46$.

Ward, Felix. 2017. "Spotting the Danger Zone: Forecasting Financial Crises with Classification Tree Ensembles and Many Predictors." L. Appl. Econometrics 32:359-78. 